\title{
28. THE STRATIGRAPHY OF NEOGENE SILICOFLAGELLATES FROM THE NORWEGIAN SEA, ODP LEG 1041
}

\author{
Paul F. Ciesielski, Phyllis Hasson, ${ }^{2}$ and James W. Turner, $\mathrm{Jr}^{3}$
}

\begin{abstract}
A quantative study was made of silicoflagellates recovered from Sites 642 (lower Miocene-upper Pliocene), 643 (lower Miocene-upper Miocene), and 644 (upper Pliocene-Quaternary) on the Vøring Plateau. Although disconformities are present in these sequences, they represent a much more complete record of the Neogene than was recovered previously in the Norwegian Sea by DSDP Leg 38.

Silicoflagellates are rare or absent for glacial sequences younger than $2.65 \mathrm{Ma}$, and generally sparse and poorly preserved in the lower upper Pliocene and upper Miocene. Lower and middle Miocene assemblages are diverse and generally well preserved. Temporal changes in the silicoflagellate assemblage are indicative of major paleoceanographic changes in the Norwegian Sea. A regional zonation for the Neogene of the Norwegian Sea is proposed, consisting of eleven zones: Naviculopsis lata Zone, $N$. quadrata Zone (emended), $N$. ponticula Zone (emended), Distephanus speculum hemisphaericus Zone (new), Caryocha ernestinae Zone (new), Bachmannocena circulus var. apiculata/Caryocha Zone (new), Distephanus crux scutulatus Zone (new), Bachmannocena diodon nodosa Zone (new), Distephanus boliviensis Zone (new), Ds. jimlingii Zone (elevated from subzonal to zonal status) with Subzones a and b (new), and $D s$. speculum Zone (new). The ranges and abundances of over 100 species and morphotypes are tabulated.
\end{abstract}

\section{INTRODUCTION}

The ODP Leg 104 drilling program was intended to examine the nature and origin of the Vøring marginal high and the Cenozoic paleoenvironment of the Norwegian-Greenland Sea, with eight holes drilled at three sites (Sites 642, 643, and 644; Fig. 1) along a short transect roughly perpendicular to the Vøring Plateau margin (Eldholm, Thiede, Taylor, et al., 1987). Our major emphasis here is on the silicoflagellate biostratigraphy of the Neogene sedimentary sequences recovered by Leg 104 . In a separate contribution Ciesielski and Case (this volume) present a paleoenvironmental interpretation of the silicoflagellate assemblages described herein.

ODP Leg 104 drilled the first sedimentary sequences in the Norwegian Sea since the initial drilling in the region by Deep Sea Drilling Project Leg 38. Seventeen sites were drilled in the Norwegian-Greenland Sea by Leg 38; however, they were discontinuously rotary-cored, providing a sporadic record of the middle Eocene to Quaternary (Talwani, Udintsev, et al., 1976). In contrast, the three sites drilled by Leg 104 on the Vøring Plateau were continuously cored using nondisturbance coring techniques (Advanced Piston Corer (APC) and Extended Core Barrel Corer $(\mathrm{XCB})$, providing the first undisturbed continuous sedimentary sequences from the Norwegian Sea.

The silicoflagellate-bearing sedimentary sequences recovered by Leg 104 include the lowermost Miocene to upper Pliocene. Silicoflagellates were extremely rare or absent from the Eocene and Oligocene of Site 643 and from the uppermost Pliocene and Quaternary at all three sites. A quantitative study of these silicoflagellate-bearing sequences is the basis of a local silicoflagellate zonation for the Neogene of the Norwegian Sea.

\section{PREPARATION OF SAMPLES AND METHOD OF STUDY}

All samples were collected by the Shipboard Scientific Party during Leg 104. Raw samples were placed in $200-\mathrm{mL}$ beakers and heated with

${ }^{1}$ Eldholm, O., Thiede, J., Taylor, E., et al., 1989. Proc. ODP, Sci. Results, 104: College Station, TX (Ocean Drilling Program).

2 Department of Geology, University of Florida, Gainesville, FL 32611.

3 Present address: Department of Geology, Ohio State University, 125 South Oval Mall, Columbus, $\mathrm{OH}$. diluted hydrogen peroxide to disassociate the sediment and remove the organic carbon. Hydrochloric acid was then added to dissolve any carbonate present in the samples. The undissolved residues were diluted with distilled water, centrifuged, and decanted to remove the acid. This procedure was repeated three times. Next, the samples were washed with sodium pyrophosphate, centrifuged, and decanted to remove a significant proportion of clay present. This final processing step was repeated until the sediment suspension obtained a neutral $\mathrm{pH}$. Processed residues were diluted with distilled water and stored in $50-\mathrm{mL}$ plastic bottles. Whole fraction slides were made of processed residues utilizing the random settling technique (Moore, 1973; Laws, 1983), which provides an even distribution of all particle sizes on a slide.

Absolute abundances of silicoflagellate taxa are recorded in the accompanying Tables 1-3. A minimum of six traverses were made of each slide; if no whole or fragmented specimens were found, the sample was recorded as barren. If whole or fragmented silicoflagellates were encountered in the first six traverses, the entire slide was examined.

Photomicrography of many silicoflagellates was made from sieved ( $>45 \mu \mathrm{m}$ ) slide preparations to eliminate the clay fraction. For this reason, some specimens of rare species are shown in the plates but are not in the tables, which present census data from whole fraction slides. Some photographed specimens are from Hole $642 \mathrm{~B}$, from which we recovered the same sequence as in Hole $642 \mathrm{C}$. Eldholm, Thiede, Taylor, et al. (1987) may be consulted to find the sub-bottom relationship between the two holes.

\section{ZONATION}

Previous studies of Neogene silicoflagellates from the Norwegian-Greenland Sea include those of DSDP Leg 38 sequences by Martini and Müller (1976) and Bukry (1976c). Bukry's study (1976c) is of little usefulness for biostratigraphic calibration of the Leg 104 Neogene because only six Neogene samples were examined. Martini and Müller (1976) described the Eocene to Pleistocene silicoflagellate assemblages from Leg 38 sites. The most complete Neogene sequence studied by Martini and Müller (1976) is that of Site 338, in close proximity to all Leg 104 sites on the Vøring Plateau. Unfortunately, most of the Hole 338 silicoflagellate assemblage is older than that encountered in the Neogene of Leg 104 sequences. Due to the lack of suitable correlative sections in the Norwegian Sea, a local zonal scheme is utilized in the present study. Taxa used to define zonal boundaries are ones which are common and exhibit the least diachroneity between Sites 642 and 643 . 


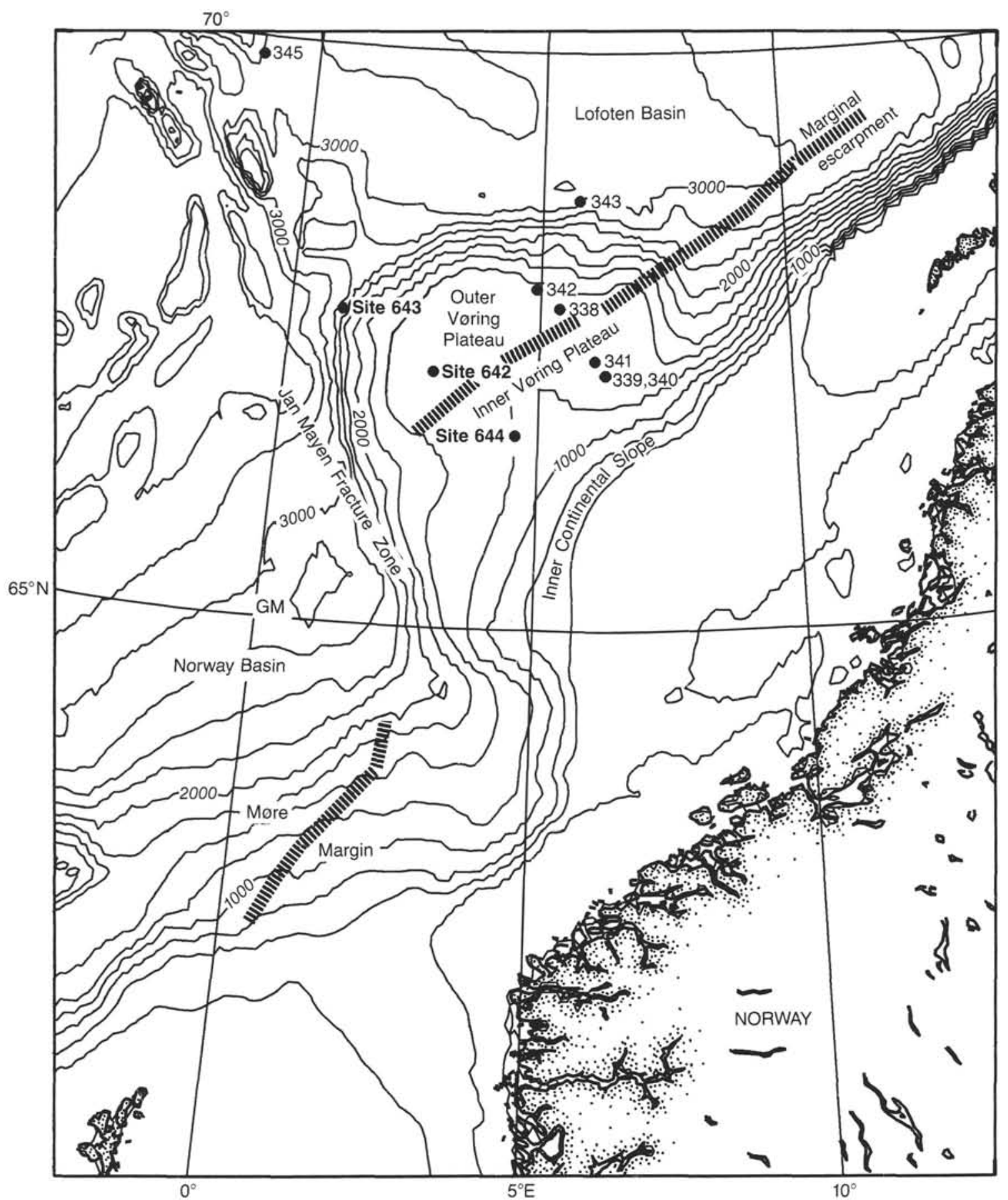

Figure 1. Bathymetry of the Norwegian continental margin (contour interval, $250 \mathrm{~m}$ ) showing the location of Leg 104 and Leg 38 sites.

Silicoflagellates described from the Neogene of Leg 104 sites are for the most part cosmopolitan species which have been noted throughout the Pacific, Atlantic, and the high-latitude regions of both hemispheres. Unfortunately, very few studies were of sufficient detail to document the ranges of the diverse silicoflagellate assemblage, particularly those of the middle to upper Miocene.

The cosmopolitan nature of the Norwegian Sea silicoflagellate assemblage and its diversity should allow a much greater biostratigraphic resolution in the future than is presently possible. Our objective is to quantitatively document the Neogene silicoflagellate assemblages of Leg 104 sequences so future biostratigraphic interpretation is possible. Ongoing research of Leg 114 subantarctic Neogene sequences (by Ciesielski) with paleomagnetic control may allow much more precise stratigraphic knowledge of Leg 104 sections in the near future.

\section{Naviculopsis lata Zone}

\section{Definition}

Interval from the first Naviculopsis lata to the first $N$. quadrata (Martini, 1972, emend. Bukry, 1978a). 


\section{Assemblage}

The most common species of the zone in Hole 642D include: Distephanus crux s.1., Ds. crux scutulatus, Ds. crux parvus, Ds. stradneri, Ds. slavincii, Ds. boliviensis (hemisphaericoid), Ds. speculum hemisphaericus, Bachmannocena apiculata curvata, and Corbisema triacantha. The genus Naviculopsis accounts for 2 to $15 \%$ of the assemblage, comprised primarily of $N$. lata, $N$. navicula, and $N$. punctilia.

\section{Datums}

1. The last consistent common occurrence $(>15 \%)$ of the genus Corbisema (Ciesielski and Case, this volume) in Sample 104-642D-10X-2, 110-113 cm.

2. First Appearance Datum (FAD) of N. navicula in Sample 104-642D-9X-5, 109-112 cm.

3. Last Appearance Datum (LAD) of N. biapiculata in Section 104-642D-10X, CC.

4. LAD of Corbisema flexuosa in Sample 104-642D-10X-5, $110-113 \mathrm{~cm}$. (occurs slightly higher in the $N$. quadrata Zone of Hole 643A).

\section{Remarks}

The portion of the zone represented here belongs to the lower Miocene. An estimate for the age of this zone may be obtained by a comparison of silicoflagellate ranges with those tabulated by Martini (1979) at Site 407 , at a similar latitude $\left(\sim 64^{\circ} \mathrm{N}\right)$ on the western flank of the Reykjanes Ridge. At Site 407, silicoflagellates occur together with calcareous nannofossils providing a means of direct correlation to standard calcareous nannofossil zones. All four datums listed above occur in the upper $\mathrm{NNl}$ calcareous nannofossil zone at Site 407. N. quadrata only occurs in one sample from Site 407 , where it is found in lower calcareous nannofossil Zone NN2. According to the time scale of Berggren et al. (1985) and the correlations to Site 407, Cores 104-642D-9 and -10 are equivalent to lower Chron $\mathrm{C} 6 \mathrm{~B}$ and upper Chron $\mathrm{C} 6 \mathrm{C}$. The upper boundary of the zone most likely occurs in lower NN2 or near Chron C6B. The portion of N. lata zone represented here is estimated therefore to have an age of $\sim 22.6$ to 23.4 Ma.

\section{Interval}

Samples $104-642 \mathrm{D}-10 \mathrm{X}-5,110-113 \mathrm{~cm}$ to $-642 \mathrm{D}-8 \mathrm{X}-5,122-$ $124 \mathrm{~cm}$. Hole $643 \mathrm{~A}$, not present.

\section{Naviculopsis quadrata Zone}

\section{Definition}

Interval defined by the total range of Naviculopsis quadrata (Bukry and Foster, 1974; Ciesielski, et al., emended herein).

\section{Assemblage}

Most common species include: Distephanus crux s.1., Ds. crux scutulatus, Ds. crux parvus, Ds. stradneri, Ds. speculum hemisphaericus, Ds. boliviensis (hemisphaericoid), and Ds. slavincii. Species of $N$. aviculopsis include: $N$. navicula, $N$. ponticula ponticula, $N$. ponticula spinosa, $N$. quadrata, $N$. lata, and $N$. biapiculata.

\section{Datums}

1. FAD of Caryocha, C. ernestinae in Sample 104-642D-7X$5,120-122 \mathrm{~cm}$ and $C$. depressa in Sample 104-642D-7X-2, 120$122 \mathrm{~cm}$.

\section{Remarks}

Bukry and Foster (1974) defined the zone as the interval from the first $N$. quadrata to the first $N$. ponticula or last $N$. quadrata. Since $N$. ponticula is very rare and occurs prior to the last $N$. quadrata, the top of the zone is redefined, thus making this a total range zone. The last occurrence of the name species is not well documented; however, based upon European land sections Martini (1972) correlated it to approximately the NN3/ NN4 boundary, which is assigned an age of 17.4 Ma by Berggren et al. (1985). In a later study, Martini (1979) found the only occurrence of $N$. quadrata in Site 407 on the Reykjanes Ridge to be within calcareous nannofossil zone NN2. Given the close proximity of Site 407 to Leg 104 sites, it appears likely that this zone encompasses most of NN2; however, it is uncertain that it also includes most or all of NN3 as it does in European sections. The maximum age range for the zone is likely from $\sim 22.6$ to $17.4 \mathrm{Ma}$ (lower NN2 through NN3), although it appears unlikely that there was continuous deposition at Sites 642 and 643 during this interval.

\section{Interval}

Sample $104-642 \mathrm{D}-8 \mathrm{X}-2,122-124 \mathrm{~cm}$ to $-642 \mathrm{D}-7 \mathrm{X}-2,120$ $122 \mathrm{~cm}$. Sample 104-643A-29X-5, 70-72 $\mathrm{cm}$ to $-643 \mathrm{~A}-28 \mathrm{X}-6$, $70-72 \mathrm{~cm}$.

\section{Naviculopsis ponticula Zone}

\section{Definition}

Interval from the last Naviculopsis quadrata to the last occurrence of the genus Naviculopsis (Bukry, 1981b; Ciesielski, et al., emended herein).

\section{Assemblage}

Same as the $N$. quadrata Zone except for the absence of $N$. quadrata.

\section{Datums}

1. LAD of $N$. navicula.

2. LAD of $N$. lata.

\section{Remarks}

The base of the zone is emended as described for the top of the preceeding zone. Bukry (1981b) found this short zone in several DSDP holes from the Atlantic, indicating that the other species of Naviculopsis range higher than the last occurrence of $N$. quadrata. This was confirmed in Holes $642 \mathrm{D}$ and $643 \mathrm{~A}$ where the genus was found only slightly higher than the $N$. quadrata Zone. According to Perch-Nielsen (1985), Naviculopsis has its last occurrence in calcareous nannofossil zone NN4. The age range for the zone is probably somewhat less than the age range of $\mathrm{NN} 4(\sim 17.4$ to $16.2 \mathrm{Ma})$.

\section{Interval} CC.

Sample 104-642D-6X-4, 115-117 cm. Section 104-643A-27X,

\section{Distephanus speculum hemisphaericus Zone.}

\section{Definition}

Interval from the last Naviculopsis to the last Distephanus speculum hemisphaericus (Ciesielski, et al., herein).

\section{Assemblage}

Dominated by Distephanus crux parvus, Ds. crux s.l., Ds. boliviensis, Ds. speculum (bolivienoid), Ds. speculum hemisphaericus, Ds. boliviensis (hemisphaericoid), Ds. stradneri, and Ds. slavincii. Consistently present, but less common are Bachmannocena apiculata curvata and Caryocha depressa. 


\section{Datums}

1. FAD of Distephanus hannai in Samples 104-642C-23H-2, $125-128 \mathrm{~cm}, 104-643 \mathrm{~A}-22 \mathrm{X}-5,69-71 \mathrm{~cm}$.

2. FAD of Bachmannocena diodon nodosa in Samples 104$642 \mathrm{C}-24 \mathrm{H}-4,125-128 \mathrm{~cm}, 104-643 \mathrm{~A}-13 \mathrm{H}-2,69-71 \mathrm{~cm}$.

3. LAD of Distephanus boliviensis (hemisphaericoid) in Sample $104-642 \mathrm{C}-21 \mathrm{H}-5,125-128 \mathrm{~cm}$.

\section{Remarks}

This long-ranging zone is equivalent to most of the Corbisema triacantha Zone defined by Locker and Martini (1985) as extending from the last occurrence of the genus Naviculopsis species to the last occurrence of Corbisema triacantha. Although generally rare and sporadically present, $C$. triacantha is found throughout the zone, indicating that the top of the zone is no younger than calcareous nannofossil zone NN6. The last occurrence of Distephanus speculum hemisphaericus is used as a zonal marker because of the scarcity of $C$. triacantha in high latitudes such as the Norwegian Sea.

The Distephanus speculum hemisphaericus Zone correlates to the following North Pacific diatom zones (defined in Barron, 1985): the upper portion of the Thalassiosira fraga Zone, Actinocyclus ingens Zone, and Subzone a and b of the Denticulopsis lauta Zone. Accordingly, the zone brackets the lower/middle Miocene boundary and encompasses most of calcareous nannofossil zone NN4, NN5, and possibly lower NN6.

\section{Interval}

Samples 104-642D-6X-2, 125-127 cm to $-642 \mathrm{C}-21 \mathrm{H}-5,125-$ $128 \mathrm{~cm}$. Samples $104-643 \mathrm{~A}-27 \mathrm{X}-6,70-72 \mathrm{~cm}$ to $-643 \mathrm{~A}-13 \mathrm{H}-2$, $70-72 \mathrm{~cm}$.

\section{Caryocha ernestinae Zone}

\section{Definition}

Interval from the last Distephanus speculum hemisphaericus to the first Bachmannocena circulus var. apiculata (Ciesielski, et al., herein).

\section{Assemblage}

Dominated by cruxoid silicoflagellates including Distephanus crux s.1., Ds. crux parvus, Ds. crux scutulatus, and Ds. stradneri. Consistently present are common Caryocha depressa and C. ernestinae, Distephanus boliviensis, and Ds. speculum (bolivienoid). In general, the zone marks the conspicuous middle Miocene demise of multiple-windowed silicoflagellates, except for Caryocha spp.

\section{Datums}

1. LAD of Distephanus slavincii in Sample 104-642C-21H$2,125-128 \mathrm{~cm}$.

2. FAD of Bachmannocena diodon diodon in Sample 104$642 \mathrm{C}-20 \mathrm{H}-5,125-128 \mathrm{~cm}$.

\section{Remarks}

This zone represents a brief stratigraphic interval of the middle Miocene. In Hole $642 \mathrm{C}$ the zone brackets the boundary between the Denticulopsis lauta and $D$. hustedtii- $D$. lauta diatom zones (Ciesielski, unpublished) with an assigned age of $13.7 \mathrm{Ma}$. Rare occurrences of Corbisema triacantha suggest that the $\mathrm{Ca}$ ryocha ernestinae Zone is correlative with the upper Corbisema triacantha Zone utilized by Martini and Müller (1976) in their silicoflagellate zonation of DSDP Leg 38 sites from the Norwegian-Greenland Sea.

\section{Interval}

Samples $104-642 \mathrm{C}-21 \mathrm{H}-2,125-128 \mathrm{~cm}$ to $-642 \mathrm{C}-20 \mathrm{H}-5,125-$ $128 \mathrm{~cm}$. Sample 104-643A-12H-5, 70-72 cm.

\section{Bachmannocena circulus var. apiculata/Caryocha concurrent range zone.}

\section{Definition}

Interval from the first Bachmannocena circulus var. apiculata to the last Caryocha spp. (Ciesielski, et al., herein).

\section{Assemblage}

Dominated by quadrate species of Distephanus including $D s$. crux s.l., Ds. crux parvus, Ds. crux scutulatus, and Ds. crux hannai. Other important contributions to the assemblage include: Caryocha depressa, C. ernestinae, Bachmannocena circulus var. apiculata, B. apiculata curvata, B. diodon nodosa (rare), and $B$. diodon diodon (rare). Distephanus species with a hexagonal basal ring are common in Hole 643A but sparse in Hole $642 \mathrm{C}$, possibly reflecting paleoceanographic differences between these two sites.

\section{Datums}

Numerous species exhibit their last occurrence at this level in Holes $642 \mathrm{C}$ and 643A (Tables 1 and 2). This pile-up of last occurrences is attributed to a major disconformity at this level. More complete sequences of the upper middle Miocene to lower upper Miocene are needed to evaluate the stratigraphic ranges of species with first or last occurrences at this disconformity.

\section{Remarks}

The previous study of silicoflagellates from the Iceland Plateau by Martini and Müller (1976) reveals that $B$. circulus var. apiculata and Caryocha have concurrent ranges throughout Cores 12 to 18 .

\section{Interval}

Sample 104-642C-20H-2, 125-128 cm. Sample 104-643A-12H2, 70-72 cm.

\section{Distephanus crux scutulatus Zone}

\section{Definition}

Interval from the last Caryocha spp. to the last Distephanus crux scutulatus (Ciesielski, et al., herein).

\section{Assemblage}

The assemblage characteristics are best demonstrated in Hole $642 \mathrm{C}$, where more of the zone is represented. The variety of quadrate Distephanus species is less than in the preceeding zone with only Ds. crux scutulatus consistently present. Species of Bachmannocena present include: $B$. circulus var. apiculata, $B$. dumitricae, $B$. diodon nodosa, and $B$. diodon diodon. Common to abundant throughout are Distephanus boliviensis and Ds. speculum (bolivienoid).

\section{Datums}

1. LAD of Distephanus crux parvus in Sample 104-642C$18 \mathrm{H}-2,125-128 \mathrm{~cm}$.

2. LAD of Ds. hannai in Sample 104-642C-18H-2, 125-128 $\mathrm{cm}$.

3. LAD of Ds. stradneri in Sample 104-642C-18H-2, 125$128 \mathrm{~cm}$. 


\section{Remarks}

The base of the Distephanus crux scutulatus Zone in Holes $642 \mathrm{C}$ and 643 is a disconformity. All but the youngest portion of the zone is missing in Hole 643A (see Goll, this volume) accounting for the absence of the above-mentioned datums.

The disconformable base of this zone is accompanied by the first occurrence of the foraminifer Neogloboquadrina acostaensis (Spiegler and Jansen, this volume) which marks the base of the upper Miocene.

\section{Interval}

Samples $104-642 \mathrm{C}-19 \mathrm{H}-5,125-128 \mathrm{~cm}$ to $-642 \mathrm{C}-17 \mathrm{H}-5,125-$ $126 \mathrm{~cm}$. Samples $104-643 \mathrm{~A}-11 \mathrm{H}-2,70-72 \mathrm{~cm}$ to $-643 \mathrm{~A}-11 \mathrm{H}-1$, $70-72 \mathrm{~cm}$.

\section{Bachmannocena diodon nodosa Zone}

\section{Definition}

Interval from the last Distephanus crux scutulatus to the last Bachmannocena diodon nodosa (Ciesielski, et al., herein).

\section{Assemblage}

The Bachmannocena diodon nodosa Zone is notable for being the oldest stratigraphic interval characterized throughout by poor preservation. The interval is also noted for its conspicuous absence of quadrate Distephanus species, except for rare Ds. crux, which were dominant components of the lower and middle Miocene assemblage. Cold water distephanids with a hexagonal basal ring dominate along with fewer numbers of Bachmannocena diodon nodosa, $B$. dumitricae, and $B$. circulus var. apiculata.

\section{Remarks}

The first and only occurrence of Neonaviculopsis neonautica occurs in the upper portion of the zone. Locker and Martini (1985) directly correlated the range of Neonaviculopsis with the upper NN11b to within NN12. This zone is also correlative to the Denticulopsis hustedtii Zone, Subzone b of the North Pacific diatom zonation (Barron, 1985). Based upon correlation of the Bachmannocena diodon nodosa zone to the diatom zonation of Leg 104 (Ciesielski, et al., unpublished), this zone encompasses the middle upper Miocene.

\section{Interval}

Samples $104-642 \mathrm{C}-17 \mathrm{H}-2,126-129 \mathrm{~cm}$ to $-642 \mathrm{C}-15 \mathrm{H}-5,125-$ $127 \mathrm{~cm}$. Samples $104-643 \mathrm{~A}-10 \mathrm{H}-5,68-70 \mathrm{~cm}$ to $-643 \mathrm{~A}-8 \mathrm{H}-5$, $67-69 \mathrm{~cm}$.

\section{Distephanus boliviensis Zone}

\section{Definition}

Interval from the last Bachmannocena diodon nodosa to the first Distephanus jimlingii (Ciesielski, et al., herein).

\section{Assemblage}

The assemblage is dominated by cold-water distephanids with a hexagonal basal ring. Quadrate distephanids are rare and may be reworked. Bachmannocena diodon diodon is common in the lower portion of the zone. Poor preservation and the rare occurrence of $B$. elliptica and $B$. circulus var. apiculata prevent reliable delineation of their upper ranges.

\section{Remarks}

Until such time as an upper Miocene sequence with good preservation can be identified in the region, this zone may be utilized to indicate the upper upper Miocene. The zone corresponds to the upper Miocene portion of Subzone a of the Denticulopsis kamtschatica diatom Zone (Ciesielski, unpublished) and encompasses most of the paleomagnetic Chrons C3AR and C3AN.

\section{Interval}

Samples $104-642 \mathrm{C}-15 \mathrm{H}-2,125-127 \mathrm{~cm}$ to $-642 \mathrm{C}-12 \mathrm{H}-2,120$ $122 \mathrm{~cm}$. Hole $643 \mathrm{~A}$, not present.

\section{Distephanus jimlingii Zone}

\section{Definition}

The zone is defined by the total range of the name species.

\section{Assemblage}

In the reference site, Site $642 \mathrm{C}$, the zone is lacking in-situ Dictyocha spp. and is dominated by cold-water distephanids.

\section{Remarks}

Bukry and Monechi (1985) previously used the range of Distephanus jimlingii to define the Ds. jimlingii Subzone of the Dictyocha fibula Zone in their study of northwestern Pacific Leg 86 DSDP sites. Lacking the Dictyocha species so often utilized in zonal schemes of the Pliocene (Perch-Nielsen, 1985), the Distephanus jimlingii Subzone is herein elevated to zonal status for use in the Norwegian Sea.

Ds. jimlingii appears to have been widespread during the Pliocene in the mid- to high-latitude North Pacific (Bukry, 1975b, 1981a; Ling, 1973, 1975) and North Atlantic (Bukry, 1979, 1984). In Leg 63 sites off the California coast, Bukry (1981a) found the species in the lower Pliocene correlative with calcareous nannofossil zone CN10. Closer to the Norwegian Sea, Bukry (1979) also noted the co-occurrence of Ds. jimlingii in the lower Pliocene of the Rockall Bank and in the Pliocene of Site 407 $\left(\sim 64^{\circ} \mathrm{N}\right)$ on the western flank of the Reykjanes Ridge.

Second-order correlation of the range of Ds. jimlingii to the paleomagnetic time scale can be made by examination of the documented range of the species relative to the diatom zones in Leg 57 sites off northeastern Japan (Barron, 1980). Barron states that Ds. jimlingii ranges from the upper portion of Subzone a of the Denticulopsis kamtschatica diatom zone to the upper Denticulopsis seminae var. fossilis-D. kamtschatica Zone. Calibration of these diatom zones to paleomagnetic stratigraphy indicates that the range of Ds. jimlingii extends from near the Miocene/Pliocene boundary to the middle or late Gauss.

In Hole $642 C$, Ds. jimlingii has its first occurrence just below a paleomagnetic reversal, between Samples 104-642C-11H$5,41 \mathrm{~cm}$ and $104-642 \mathrm{C}-11 \mathrm{H}-5,111 \mathrm{~cm}$ (Bleil, this volume), suggesting that this reversal was correctly identified as the Chron C3AN/Gilbert Chron boundary. The age of the top of the zone cannot be accurately defined in Hole $642 \mathrm{C}$ where the last occurrence of the species coincides with the base of the overlying barren interval. At Site $644 \mathrm{~A}$, Ds. jimlingii is absent in Gauss Chron sediments (2.84-2.65 Ma) beneath a similar barren inter$\mathrm{val}$. Thus, the last occurrence of the species and the top of the zone must occur within the Gauss Chron, prior to $2.84 \mathrm{Ma}$, in close agreement with its age defined by second-order correlation to paleomagnetic stratigraphy as discussed previously. The age of the zone is estimated therefore to be between approximately 5.5 and $2.9 \mathrm{Ma}$.

\section{Interval}

Samples $104-642 \mathrm{C}-11 \mathrm{H}-5,141-143 \mathrm{~cm}$ to $-642 \mathrm{C}-9 \mathrm{H}-2,103-$ $105 \mathrm{~cm}$. Hole 643A, not present. Sample 104-644A, not present. 


\section{Distephanus jimlingii Zone, Subzone a}

\section{Definition}

Interval from the first occurrence of Distephanus jimlingii to the first Ds. sulcatus (Ciesielski, et al., herein).

\section{Assemblage}

Includes a variety of Distephanus species (see Table 1). Rare Bachmannocena circulus var. apiculata occur and a transitionary morphotype between Ds. sulcatus and Ds. jimlingii (tabulated as Ds. jimlingii/sulcatus) appears in the upper portion of the subzone.

\section{Remarks}

The age of the subzone ranges from $\sim 5.5 \mathrm{Ma}$ to the middle Gauss paleomagnetic Chron.

Interval

Samples 104-642C-11H-5, 141-143 cm to $-642 \mathrm{C}-10 \mathrm{H}-2,124-$ $126 \mathrm{~cm}$. Hole 643A, not present. Hole 644A, not present.

\section{Distephanus jimlingii Zone, Subzone b}

\section{Definition}

Interval from the first occurrence of Distephanus sulcatus to the last Ds. jimlingii (Ciesielski, et al., herein).

\section{Assemblage}

The assemblage of this subzone differs little from that described for the zone except for the added presence of Distephanus sulcatus and the lack of Bachmannocena.

\section{Remarks}

Distephanus sulcatus is a large and easily identified silicoflagellate with an abrupt appearance. The base of the subzone occurs in the mid-Gauss paleomagnetic Chron according to the paleomagnetic stratigraphy of Hole $642 \mathrm{C}$ (Bleil, this volume).

\section{Interval}

Sample 104-642C-9H-2, 103-105 cm. Hole 643A, not present. Hole $644 \mathrm{~A}$, not present.

\section{Distephanus speculum Zone}

\section{Definition}

Interval from the last Distephanus jimlingii to the last consistent occurrence of frequent to common silicoflagellates at the base of the upper Pliocene-Quaternary glacial sequence.

\section{Assemblage}

Consists mainly of Distephanus speculum, Ds. boliviensis, Ds. sulcatus, and Ds. crux.

\section{Remarks}

The base of the zone was unrecovered, but is estimated to be approximately $2.9 \mathrm{Ma}$ as discussed in the remarks for the previous zone. The top of the zone has an age of $2.65 \mathrm{Ma}$ based upon direct correlation to the paleomagnetic record of Hole $644 \mathrm{~A}$ as defined by Bleil (this volume).

\section{Interval}

Samples $104-644 \mathrm{~A}-34 \mathrm{H}-5,70-72 \mathrm{~cm}$ to $-644 \mathrm{~A}-32 \mathrm{H}-1,70-72$ $\mathrm{cm}$. Hole $643 \mathrm{~A}$, not present. Hole $642 \mathrm{C}$, not present.

\section{BIOSTRATIGRAPHY}

\section{Site 642 (Table 1)}

Samples 104-642C-1H-1, 125-127 cm through 104-642C-8H$2,124-126 \mathrm{~cm}$ are barren of silicoflagellates. Reference to the paleomagnetic stratigraphy of this interval (Bleil, this volume) indicates that the barren zone is Brunhes to late Gauss in age ( 0-2.5 Ma). In Hole 644A, a similar upper Pliocene to Quaternary barren zone was encountered that has confidently been assigned an age of 0-2.65 Ma.

The Distephanus jimlingii Zone was identified between Samples $104-642 \mathrm{C}-9 \mathrm{H}-2,103-105 \mathrm{~cm}$ and $104-642 \mathrm{C}-11 \mathrm{H}-5,141-$ $143 \mathrm{~cm}$. This interval is dominated by species of cold-water distephanids with the most common constituents being Distephanus jimlingii, Ds. frugalis, Ds. sulcatus, Ds. speculum, Ds. boliviensis, and cannopilean Ds. boliviensis. Because of the absence of Ds. jimlingii in 644A, the last occurrence of silicoflagellates in Hole $642 \mathrm{C}$ is older that the $2.84-\mathrm{Ma}$ age of the oldest sample examined from Hole 644A. Thus, if no unconformity is present at the base of the overlying barren zones at both sites, there was a diachronous last occurrence of silicoflagellates within the Gauss between Sites 642 and 644 .

The interval between Samples 104-642C-12H-2, 120-122 cm and $104-642 \mathrm{C}-15 \mathrm{H}-2,125-127 \mathrm{~cm}$ is assigned to the Distephanus boliviensis Zone. Silicoflagellates are sparse and are dominated by long-ranging species. Two samples, 104-642C-14H-2, $124-126 \mathrm{~cm}$ and $104-642 \mathrm{C}-15 \mathrm{H}-2,125-127 \mathrm{~cm}$, contain Bachmannocena diodon diodon and Distephanus speculum giganteus which occur together in the uppermost Miocene of the Southern Ocean (Chrons 5 and 6) (Ciesielski, 1985). Although both species have their last occurrence in the latter sample, poor preservation and low abundances in the upper portion of the interval prevent reliable definition of the last occurrences of these species. Low abundances in this interval were likely caused by low surface-water productivity. Several samples include common-to-abundant entire coccospheres, indicative of poorly oxygenated benthic conditions which may have resulted from weak vertical mixing of the water column.

Sample 104-642C-15H-5, 125-127 cm contains abundant silicoflagellates dominated by Distephanus boliviensis, Ds. speculum, and many of their subspecies and morphotypes. The last joint occurrence of Bachmannocena diodon diodon and B. diodon nodosa occur in the uppermost sample of the $B$. diodon nodosa Zone. Sparse occurrences of Dictyocha brevispina and Neonaviculopsis neonautica also occur in this sample. $N$. neonautica has a restricted range that brackets the Miocene/Pliocene boundary, ranging from the base of calcareous nannofossil zone NN11b to within NN12 (Locker and Martini, 1985).

Sample $104-642 \mathrm{C}-16 \mathrm{H}-2,125-127 \mathrm{~cm}$ is barren. The remainder of the upper Miocene $B$. diodon nodosa Zone between Samples $104-642 \mathrm{C}-16 \mathrm{H}-5,125-127 \mathrm{~cm}$ and $104-642 \mathrm{C}-17 \mathrm{H}-2,126-$ $129 \mathrm{~cm}$ is characterized by very poor preservation and a sparse assemblage of silicoflagellates, diatoms (Ciesielski, this volume), and radiolarians (Goll and Bjørklund, this volume). Although all siliceous microfossil assemblages are sparse and poorly preserved, there is no evidence for a disconformity in this interval.

The last occurrence of Distephanus crux scutulatus in Sample 104-642C-17H-2, 126-129 cm marks the top of the Ds. crux scutulatus Zone that continues down to Sample 104-642C-19H$5,125-128 \mathrm{~cm}$. This zone represents the last occurrence of diverse and well-preserved silicoflagellate assemblages in the Norwegian Sea. Within this interval is the last consistent occurrence of Bachman nocena and the last significant occurrence of Dictyocha and quadrate Distephanus.

Several lines of evidence point to a significant hiatus between the base of the Ds. crux scutulatus Zone in Sample 104-642C- 
$19 \mathrm{H}-5,125-128 \mathrm{~cm}$ and the Bachmannocena circulus var. apiculata/Caryocha Zone in Sample 104-642C-20H-2, 125-128 cm. First, the concurrent ranges of $B$. circulus var. apiculata and Caryocha spp., which typify the latter zone are confined to Sample 104-642C-20H-2, $125-128 \mathrm{~cm}$. These taxa should have a considerable concurrent stratigraphic range based upon the previously mentioned study of silicoflagellates from the Iceland Plateau by Martini and Müller (1976). Second, a number of first and last occurrences occur at this level (Table 1) suggesting a truncation of numerous stratigraphic ranges. Among these is the last occurrence of the genus Caryocha which does not range into the upper Miocene. Third, other siliceous microfossil assemblages, diatoms (Ciesielski, this volume) and radiolarians (Goll and Bjørklund, this volume) document the presence of a disconformity at a similar depth. The presence of Neogloboquadrina acostaensis in Sample 104-642C-19H, CC (Spiegler and Jansen, this volume) confirms the presence of the upper Miocene in this core. These and other data indicate that the hiatus brackets the middle/upper Miocene boundary and occurs between Samples 104-642C-19H, CC and 104-642C-20H-2, $125-128 \mathrm{~cm}$.

Conformable with the $B$. circulus var. apiculata/Caryocha Zone is the underlying Distephanus speculum hemisphaericus Zone, extending between Samples 104-642C-21H-5, 125-128 cm through 104-642D-6X-2, 125-127 cm. This interval spans the upper lower Miocene through upper middle Miocene, exhibiting good preservation, high taxonomic diversity and very low taxonomic turnover. Although other microfossil groups indicate the presence of small disconformities within this interval, they are not detected in the silicoflagellate assemblages because of the lack of sufficient taxonomic turnover.

The genus Naviculopsis occurs within the lower portion of hole between Samples 104-642D-6X-4, 115-117 cm and 104642D-10X-5, 110-113 cm. In the Norwegian Sea, as elsewhere globally, this cosmopolitan genus underwent its last diversification in the early Miocene. Unfortunately, Naviculopsis species are sparse and the record of the diversification of the genus is compressed in a relatively short interval. Further, more detailed study of this interval is needed to document the range of lessabundant species. As a consequence, some established lower Miocene silicoflagellate zones based upon Naviculopsis species are not utilized for zonal boundaries in this study. Instead, this interval is subdivided based upon easily recognized datums (FAD and LAD of $N$. quadrata and the LAD of the genus Naviculopsis) into the $N$. ponticula Zone, $N$. quadrata Zone and $N$. lata Zone.

Several samples were examined from lithologic Unit IV, volcaniclastic muds, sandy muds, and sands which lie beneath the thick Miocene and Pliocene biogenic sediments of Units II and III. Sample 104-642D-11X-2, 136-139 cm is from a volcaniclastic sand, immediately below the major unconformity in Core $11 \mathrm{X}-1,94 \mathrm{~cm}$. Sample 104-642D-12X-2, 128-131 cm also is from a volcaniclastic sand, while Sample 104-642D-12X-5, 125-128 $\mathrm{cm}$ was recovered from a cyclic sequence of muds and silts. Eleven silicoflagellate species occur within these samples, which have ranges from the middle to upper early Miocene.

Unit IV was assigned an age of Eocene in the lithologic summary section of the Site 642 chapter (Eldholm, Thiede, Taylor, et al., 1987), although no reliable microfossil data were available for an age determination (see Biostratigraphy Section of Site 642 chapter of Eldholm, Thiede, Taylor, et al., 1987). The exclusive occurrence of Miocene silicoflagellates without any $\mathrm{Pa}$ leogene species suggests that the upper portion of Unit IV may be largely downhole slump from between Cores 104-642D-21H and $-642 D-5 X$. Repeated downhole slumps may account for the cyclic sediment characteristics and other structures which were previously interpreted to be indicative of shallow water deposition in an area of active mass flow activity (Eldholm, Thiede,
Taylor, et al., 1987, pp. 74-75).

Three additional samples were examined from within Unit IV and found to be barren. Of these, Samples 104-642D-13X-2, $125-128 \mathrm{~cm}$ and 104-642D-13X-4, 125-128 cm were obtained from a glauconite-rich volcanoclastic sandy mud. Sample 104$642 \mathrm{D}-14 \mathrm{X}-2,124-125 \mathrm{~cm}$ is from a volcanoclastic mud directly above Unit V. Since the lower portion of Unit IV is barren, it is much more likely in situ, in contrast to the upper portion of the unit with considerable downhole contamination.

Sample 104-642D-16X-1, 4-6 cm was obtained from a pebble horizon that occurs beneath Unit IV and directly above the 914 $\mathrm{m}$ sequence of volcanic rocks and dikes drilled in Hole 642E. Silicoflagellates are abundant, well preserved, and diverse in this sample (Table 1). The assemblage includes species common within the lower Miocene of Hole 642D and probably represents downhole slump. The presence of a few Naviculopsis specimens suggests that the sediment originated from the walls of the hole between Cores 104-642D-6X and -642D-10X. Thus, while the pebbles are in situ, the fine-grained fraction is not.

Sample 104-642D-19N-1, 92-112 cm, the basal sample examined from Hole 642D, comes from drilling rubble accompanying basaltic vitric tuff. The sample is barren of all siliceous microfossils, suggesting that the fine fraction is drilling slurry.

\section{Site 643 (Tables 2 and 3)}

Silicoflagellates are absent above Sample 104-643A-8H-5, $67-69 \mathrm{~cm}$. Upper Miocene assemblages are of low diversity and fragmented silicoflagellates generally outnumber whole specimens in Samples 104-643A-8H-5, 67-69 cm through 104-643A$11 \mathrm{H}-2,70-72 \mathrm{~cm}$. Beneath a hiatus bracketing the middle/upper Miocene boundary, silicoflagellates are abundant and diverse down to a lower Miocene diagenetic boundary $(\sim 284$ mbsf, Section 104-643A-30X, CC), below which silicoflagellates are absent.

Sample 104-643A-8H-5, 67-69 cm contains mostly fragments, but also has a few Bachmannocena diodon nodosa and fragments of $B$. circulus var. apiculata (reworked?). This sample is assigned to the $B$. diodon nodosa Zone and has an upper Miocene age. Missing in Hole 643A are the younger Distephanus speculum Zone (in Hole 644A between Samples 104-644A-34H-5, $70-72 \mathrm{~cm}$ and 104-644A-32H-1, 70-72 cm), Distephanus jimlingii Zone, Distephanus boliviensis Zone (in Hole 642 between Samples 104-642C-9H-2, 103-105 cm and 104-642C-15H-2, 125$127 \mathrm{~cm}$ ), and possibly the uppermost Bachmannocena diodon nodosa Zone. Accordingly, a hiatus must exist above Sample 104-643A-8H-5, 67- $69 \mathrm{~cm}$ which encompasses no less than the latest Miocene to late Pliocene ( $\sim 6.5$ to $2.65 \mathrm{Ma}$ ).

Sample 104-643A-9H-2, 70-72 cm also contains a high proportion of fragments, as well as Bachmannocena dumitricae (LAD), B. diodon nodosa, and $B$. circulus var. apiculata (LAD). This sample is also assigned to the $B$. diodon nodos $a$ Zone and is late Miocene in age, older than the estimated $\sim 6.5 \mathrm{Ma}$ age for the LAD of B. circulus var. apiculata (Ciesielski, 1983).

Sample 104-643A-9H-5, 69-71 cm is barren and Sample 104$643 \mathrm{~A}-10 \mathrm{H}-2,68-70 \mathrm{~cm}$ contains only fragments of silicoflagellates. Fragments are also abundant in Samples 104-643A-10H-2, $68-70 \mathrm{~cm}$ and $104-643 \mathrm{~A}-10 \mathrm{H}-5,68-70 \mathrm{~cm}$, but are also assigned to the Bachmannocena diodon nodosa Zone because of the presence of the name species and $B$. circulus var. apiculata above the last Distephanus crux scutulatus.

The upper portion of the Distephanus crux scutulatus Zone is represented in Sample 104-643A-11H-1, 70-72 cm where the last occurrence of Ds. crux scutulatus occurs. The stratigraphic level marks a major change in the silicoflagellate assemblage characterized by the demise of cruxoid forms and increased dominance of Distephanus and Bachmannocena during the middle late-to-late late Miocene. A similar assemblage occurs in Sam- 
Table 1. Leg 104, Hole 642C and Hole 642D silicoflagellate abundances, occurrences, zones, and ages. Species listing in order of highest occurrences. Intraspecific variants are listed separately with diagnostic characteristics indicated in parentheses. The key to the abbreviations indicating morphologic characteristics is as follows: $\mathbf{w} /=$ with, aw. = apical window, brs. = basal ring sides, $\mathbf{s p . ~ = ~ b a s a l ~ r i n g ~ s p i n e s , ~ b r . ~}=$ basal ring, asym. $=$ asymmetrical.

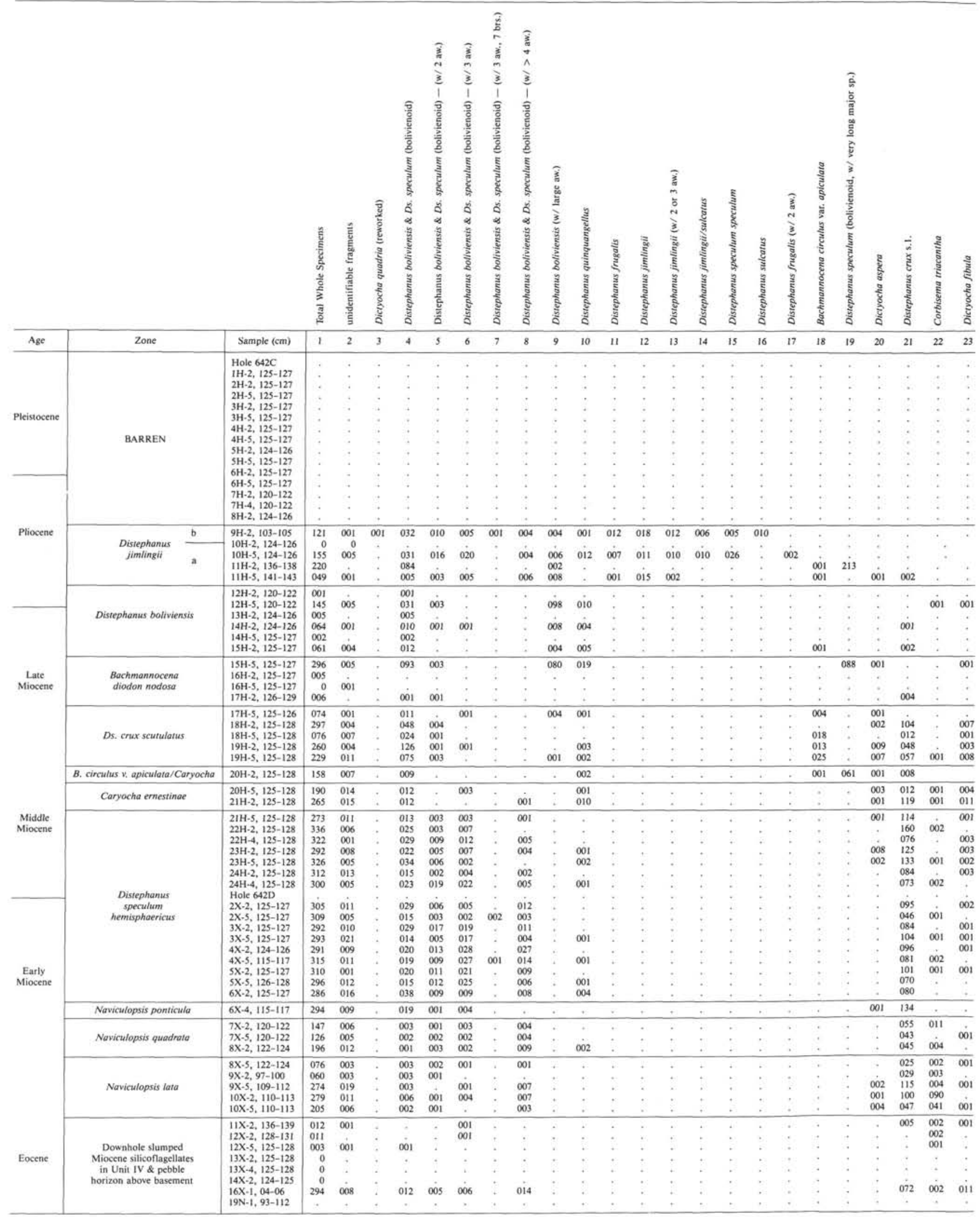




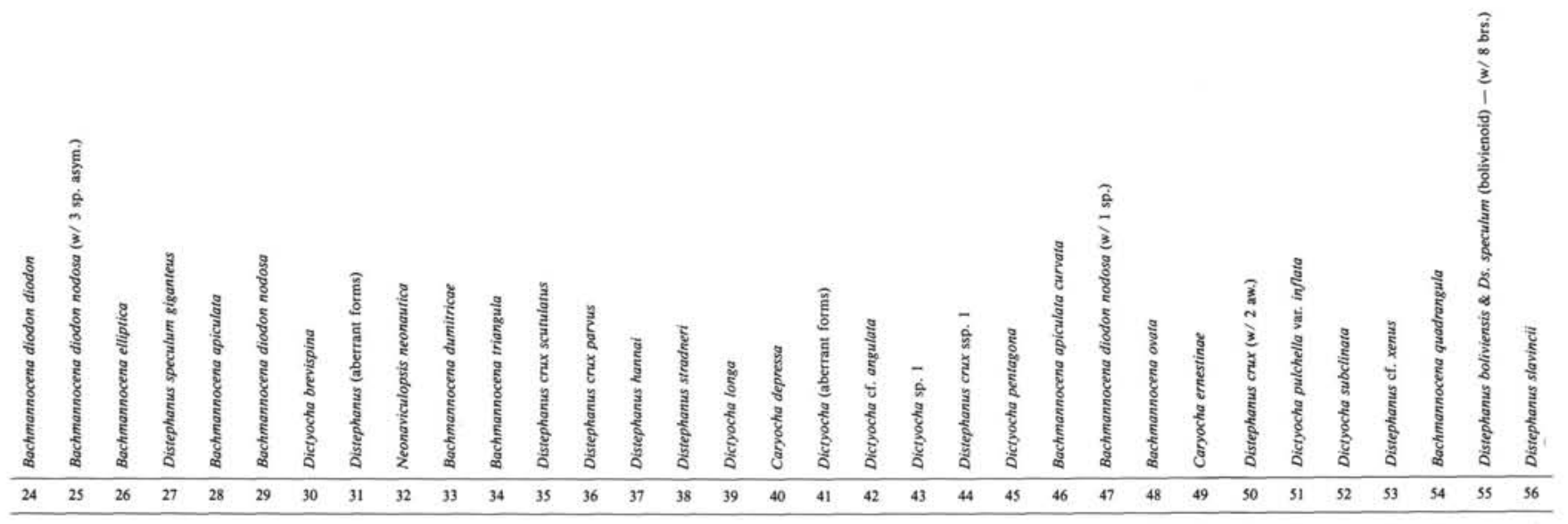

\begin{tabular}{|c|c|c|c|c|c|c|c|c|c|c|c|c|c|c|c|c|c|c|c|c|c|c|c|c|c|c|c|c|c|c|c|c|}
\hline & & & & & & & & & & & & & & & & & & & & & & & & & & & & & & & & \\
\hline 01 & 001 & $\infty 01$ & 026 & . & : & : & $\therefore$ & . & $\therefore$ & : & $\vdots$ & 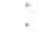 & : & 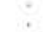 & $\vdots$ & $:$ & . & $\vdots$ & $\vdots$ & 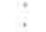 & $\vdots$ & : & $\vdots$ & $\therefore$ & $\vdots$ & $\therefore$ & : & $\vdots$ & $:$ & $\vdots$ & 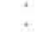 & $:$ \\
\hline & . & . & m & & . & . & . & . &. & . & . & & . & , & . & . & . & . &. & . & . & . & . &. & . & . & . &. & . & . & . & . \\
\hline 035 &. &. & 001 & 001 & . & $\cdot$ & . & . & . & . & $\cdot$ & , & . & . & . & . &. & . & . & . &. &. & $\cdot$ & . & . & . & . & . & . & . & $\cdot$ & . \\
\hline 002 & 001 & . & 001 & . & 002 & 002 & 001 & 002 & &. & 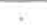 & . & . &. &. & . &. & . &. &. & . &. &. &. &. &. &. &. & . & . & . & . \\
\hline . & . & . & . & . & . & . & . & & 005 & & . & & , & . & . & . & , & . & . & & . & . & . & . & . & . & . & . & . & & . & . \\
\hline . & . & . & $\cdot$ & . & . & & . & . & . & . & . & . & & $\cdot$ & . & . & $\cdot$ & . & & . & . & . & . & . & & . & . & , & . & . & . & . \\
\hline+ &. & . & $\cdot$ & . &. &. & $\cdot$ & 5 & . & . & . & . & 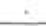 & . & . &. &. & $\cdot$ & . & . & 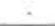 & . & . & . &. & $\cdot$ & . &. & . & . & $\cdot$ & . \\
\hline 016 & 005 & 001 & . & 001 & 018 & . & . & . & & 001 & 010 & & & &. & . & + & , & . & . & . & 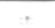 & , & , & , &. &. & . & . & $\cdot$ & . & . \\
\hline & & . & . & $\dot{s}$ & 001 & . & . & . & 001 & $\dot{x}$ & 102 & 008 & 002 & 018 & 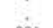 & . & . & & . & . & . & . & . & . & . & . & . & . & . & . & . & . \\
\hline 001 & 001 & . & . & 001 & 001 & & , & , & 009 & 001 & 005 & . & & , & 001 & & & & & & , & . & . & . & . & . & . &. & . & . & , & . \\
\hline 004 & 001 & , & . & $\cdot$ & 001 & . & . & & 013 & . & 028 & & & . & . & 001 & 001 & 001 & 003 & 003 & & . & . & . & . & . & . & . & . & . & . & . \\
\hline. & . & . & . & $\dot{x}$ & . & 8 & . &. & 006 & . & 039 & 001 & 001 & . &. & . & . & 001 & $\because$ & $\because$ & 002 & $:$ & . & 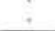 & 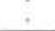 & 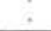 & $\therefore$ &. & &. & . & . \\
\hline 001 & 001 & 002 & . & 004 & 006 &. &. &. & 002 & . & 010 & 010 & 003 &. &. & 002 &. & 001 & . & 001 &. & 005 & 001 & 001 & 018 & 001 &. &. &. & . & , & . \\
\hline 002 & 004 & &. & . & 006 & , &. & 001 & . & & 018 & 032 & 007 & 005 & 026 &. & , & + & . &. & 007 & . &. & 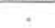 & 032 &. & 003 & 005 & 001 & & & \\
\hline . & 001 & 002 & . & . & 011 &. & . & . & . & 003 & 018 & 022 & $\infty 01$ & 012 & 019 & . & & . & . & . & . & & . & . & 007 & . & . & . & . & 007 & 002 & 006 \\
\hline & & . & , &. & 001 & . & . & . & . & 006 & 022 & 060 & . & 010 & . & 003 & , & , & , & . & . & 003 &. &. & & . &. & . & 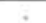 & . &. & 020 \\
\hline . & 001 & . & . & . & 002 & $\therefore$ & $\therefore$ & $\therefore$ & $\therefore$ & 003 & 020 & 069 & 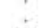 & 010 & $\therefore$ & 002 & . & : & $\because$ & : & : & . & $\therefore$ & : & 002 & $\because$ & $\therefore$ & : & . & . & . & 013 \\
\hline . & & & . & , & , & 001 & . &. &. & $\infty 01$ & 032 & 097 & 001 & 023 & & 001 & . & & & . & . & 006 & $\because$ & . & . & . & . & . & & . &. & 014 \\
\hline . & . & . & . & . & M & , & . & . & . & 007 & 015 & 043 & 004 & 028 & . & . & . & . & 001 & . & . & 010 & . & . & . & & . & . & . & . & . & 002 \\
\hline & . & . & . & . & 001 & . & & . & & & 012 & 094 & 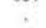 & 002 & & : & $\therefore$ & & . & & . & 001 & . & . & . &. & ? & & . & . & . & 013 \\
\hline . & & . & . & & & . & $\therefore$ & . & . & 003 & 016 & 148 & $\therefore$ & 007 & & " & . & . & $\therefore$ & : & : & 002 & : & : & & $\therefore$ & . & . & . & . & . & 019 \\
\hline . & . & . & . & . & 001 & . & . & . & ? & 002 & 016 & 089 & : & 009 & . & 001 & . & : & 001 & . & . & 004 & i & . & 001 & . & & . & . & . & . & 012 \\
\hline & $\cdot$ & $\cdot$ & & $\cdot$ & . & $\cdot$ & & . & , & & & & & (S) & & $\therefore$ & & & . & & . & . & . & $\cdot$ & & . & . & 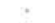 & . & . & . & \\
\hline . & $\cdot$ & . & . & . & . & 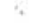 & 006 & $\cdot$ & . & 001 & 021 & 079 & . & 012 &. & 004 & . & &. & . & . & 8 & . & . & 001 & . & . & . & . & . & . & 013 \\
\hline . & . & + & . & 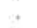 &. & . & 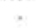 & . & . & 002 & 041 & 161 & & 006 & . & & $\therefore$ & . & . & . & . & 002 & . & . & & . & . & . & . & . & + & 015 \\
\hline & . & . & . & & . & . & $\therefore$ & : & . & 001 & 015 & 075 & & 008 & & 001 & & . & : & . & & 006 & : & . & $\therefore$ & . & . & . & . & . & . & 010 \\
\hline . & . & . & . & 003 & $\therefore$ & + & $m$ & . & . & . & 008 & 058 & . & 002 & . & 008 & $\therefore$ & & . & . & . & 004 & . & . & 003 & . & . & . & , & , & . & 001 \\
\hline . & & , & . & $\dot{\theta}$ & $\therefore$ & . & 002 & . & . & $\therefore$ & 021 & 051 & : & 010 & $\therefore$ & 001 & . & . & . & . & . & 003 & 8 & . & 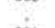 & , & $\therefore$ & . & . & . & . & 004 \\
\hline . & . & , & . & 001 & . & , & $\infty 01$ & , & , & . & 015 & 097 & . & 002 & . & & . & . & . & & , & 009 & . & . & $\infty 01$ & . & . & . & . & . & . & 002 \\
\hline . & . &. &. & . & 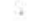 & . & &. & & . & 013 & 090 & . & 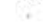 & . & 002 & . & . & . & , & . & 001 & . & . & & . & . & . & . & . & & 006 \\
\hline , & . & 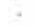 & . & 001 & . & . & . & , & . & . & 010 & 092 & & , & & 003 & , & , & . & . & . & 002 & . & . & 003 &. &. &. & . & . & . & 003 \\
\hline . & . & . &. & . & . & . & . &. &. & . & $\infty 03$ & 028 & . & . & . & 002 & & . & . & . & . & . &. & . & . & . &. & . &. & . & . & . \\
\hline . &. & $\therefore$ &. & 001 & . &. & . & 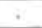 & . & 001 & 014 & 040 & . &. &. & 005 & . & . &. & , & . & 003 &. & . & $\infty 01$ & . & 001 & i & . & . & . & 006 \\
\hline & & . & . &. & . & & . & ? &. & & 007 & 026 & , & & , & 003 &. & . &. &. &. & . &. &. & &. & 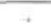 & 7 &. &. &. & 002 \\
\hline . & . & : & & & . & . & . & . & & 001 & 009 & 030 & . & 005 & . & . & . & . & & . & & & & & 001 & . & . & . & . & & . & 008 \\
\hline & . & 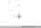 & . & . & . & . & . &. & . & 007 & 008 & 050 & . & 002 & . & . & . & . & . & . & . & 003 & . & . & . & . & . & . & . & 001 & + & 010 \\
\hline . & . & . & . & 001 & & & , & , & , & 005 & 003 & 007 & & $\infty 01$ & & & & & & . & . & 002 & & & & , & , & , & . & 001 & $\cdot$ & \\
\hline . & $\because$ & : & $\because$ & 001 & & $\because$ & $\therefore$ & & & 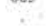 & 002 & 010 & : & $\because$ & : & $\therefore$ & $:$ & 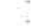 & & : & : & 001 & $\therefore$ & 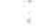 & ? & $\therefore$ & 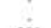 & $\therefore$ & $\because$ & 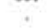 & $\therefore$ & 002 \\
\hline , &. &. &. & & . & . & & . & . & , & 011 & 071 & , & . & , & . & & & & & . & 001 & . & . & & & 001 &. & $\because$ & . & & 008 \\
\hline . & . & & & 001 &. & &. & . & . & 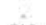 & 024 & 025 & & 001 &. & & . & . & 004 & . & . & 002 & $\therefore$ & . & . & . & . & & & . & . & . \\
\hline. & . & . &. & 006 & . & + & + &. &. & 010 & 008 & 015 & . & 014 &. & . & . & . & & . & & 010 & . & &. & $=$ &. & . &. &. & . & . \\
\hline , & . &. & . & . & . & 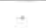 & . & . & . & . & & 001 & . & . & 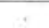 & . &. &. & 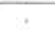 &. &. &. &. & . & . & . &. & . &. & , & . & , \\
\hline & . &. & . & & . & & . & . & . & . & 004 & 002 & & . & . & . & . & . & & & & & & & & . & & & 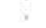 & . & . & . \\
\hline & & & & , & . & , & , & . & , & , & . & 001 &. & . & & & . & - & . & , & & , & & . & & , & , & , & , & . & & , \\
\hline . & & . & . & . & . & . & . & . & . & & & & . & . &. & & & & & & & & . & , & & & . & . & . & . & . & . \\
\hline & . & . & . & . & . & & . & & & . & . & & & , & & & & & & & & & , & & & & . & . & . & . & . & . \\
\hline & . & . & . & & . & . & . & . & & si & is & $\therefore$ & & $\therefore$ & & . & . & . & & . & . & $\therefore$ & . & . &. & . & . & . & . & . & . & $\therefore$ \\
\hline & . & & . & . & . &. & . & & . & 001 & 015 & 099 & & 004 & & . & & . & . & . & . & 007 & . & . & & . & &. & . & . & . & 001 \\
\hline$*$ & . & . & , & . & & & . & . & & . & , & , & & , & . & . & & , & & . & . & . & . & . & . & . & & . & . & . & . & . \\
\hline
\end{tabular}


Table 1 (continued).

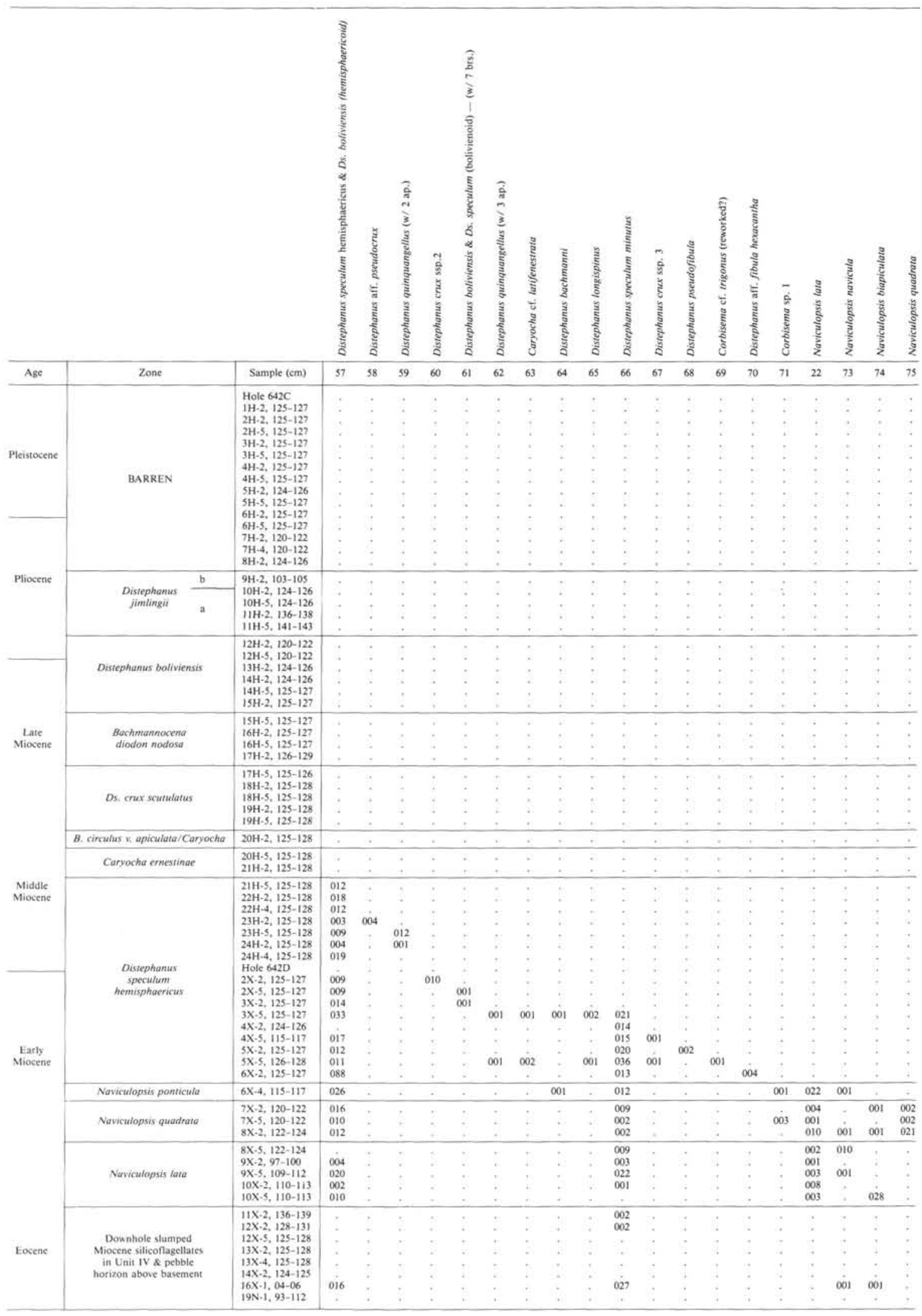




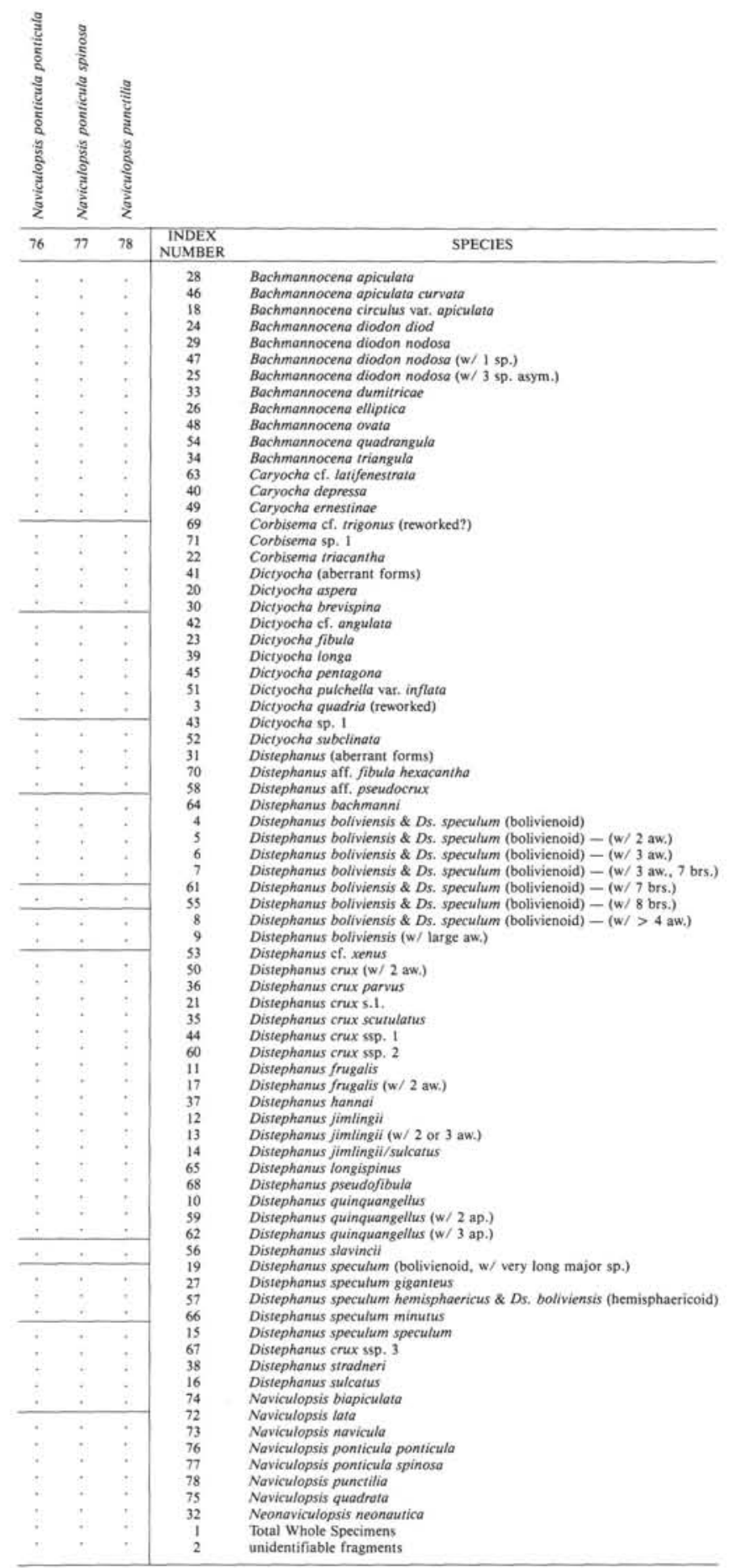

ple $104-643 \mathrm{~A}-11 \mathrm{H}-2,70-72 \mathrm{~cm}$ which is assigned to the Ds. crux scutulatus Zone. The last occurrence of Ds. longispinus in this sample is indicative of a late Miocene age, as Martini and Müller (1976) correlate this event to within calcareous nannofossil zone NN10.

The most abrupt change in the silicoflagellate assemblage of Hole 643A occurs between Samples 104-643A-11H-2, 70-72 cm and $104-643 \mathrm{~A}-12 \mathrm{H}-2,70-72 \mathrm{~cm}$. Table 2 reveals numerous last occurrences which occur in Sample 104-643A-12H-2, 70-72 cm; among those species with a last appearance at this level are Bachmannocena apiculata, Caryocha depressa, C. ernestinae, Distephanus hannai, Ds. stradneri, Ds. crux parvus, and Ds. slavincii. The multiple last appearances between these two samples are interpreted as the result of a significant hiatus between the Distephanus crux scutulatus Zone above and the Bachmannocena circulus var. apiculata-Caryocha Zone below. Missing is most of the upper portion of the B. circulus var. apiculata-Caryocha Zone that is defined by the concurrent range of these taxa. In Hole $643 \mathrm{~A}$, their concurrent range is limited to Sample 104-643A-12H-2, 70-72 cm. Elsewhere in the region (Site 348 on the Iceland Plateau), Martini and Müller (1976) documented the concurrent range of these taxa in the upper portion of their middle-late Miocene Mesocena circulus Zone. The age of the hiatus is problematic as a result of the scarcity of detailed census data of silicoflagellate assemblages across the middle/late Miocene boundary. Taxa within Sample 104-643A-12H-2, 70-72 $\mathrm{cm}$ are common constituents of the middle Miocene in Leg 104 holes and elsewhere throughout the world. On the basis of silicoflagellate assemblages, the hiatus either includes the upper middle Miocene and lowermost upper Miocene or may be confined to the lower upper Miocene.

Another hiatus may occur between Samples 104-643A-12H$2,70-72 \mathrm{~cm}$ and $-643 \mathrm{~A}-12 \mathrm{H}-5,70-72 \mathrm{~cm}$. The latter sample is assigned to the Caryocha ernestinae Zone based upon its position between the last Distephanus speculum hemisphaericus and the first Bachmannocena circulus var. apiculata. The apparent last occurrence of Corbisema triacantha in this sample is indicative of an age not younger than NN7 of the middle Miocene.

The interval between Samples 104-643A-13H-2, 70-72 cm and 104-643A- 27X-6, 70-72 cm is assigned to the Distephanus speculum hemisphaericus Zone. The silicoflagellate assemblage of this interval is remarkably uniform in comparison to younger assemblages. Quadrate Distephanus species dominate along with Caryocha and Distephanus species with a subdivided apical apparatus. The interval represents the upper lower Miocene to upper middle Miocene (NN4-NN7). Disconformites defined in this zone by diatom and radiolarian biostratigraphic zonal schemes (Goll, this volume; Ciesielski, unpublished; Goll and Bjørklund, this volume) are not evident because of the lack of significant change in the silicoflagellate assemblage.

The brief Naviculopsis ponticula Zone is recognized in Sample 104-643A- 27X, CC where several Naviculopsis species were noted above the last occurrence of $N$. quadrata in Sample 104$643 \mathrm{~A}-28 \mathrm{X}-6,70-72 \mathrm{~cm}$. The remaining two samples examined in the quantitative census of silicoflagellates, Samples 104-643A$28 \mathrm{X}-6,70-72 \mathrm{~cm}$ and $104-643 \mathrm{~A}-29 \mathrm{X}-5,70-72 \mathrm{~cm}$, both contain $N$. quadrata, indicative of the $N$. quadrata Range Zone of the lower Miocene. Although core-catcher samples are not tabulated in Table 2, shipboard examination of Section 104-643A$30 \mathrm{X}, \mathrm{CC}$ revealed the presence of the $N$. quadrata Zone, its lowermost occurrence in Hole 643A.

The base of the $N$. quadrata Zone is marked by a sudden diagenetic transition to sediments almost entirely barren of siliceous microfossils. The base of the zone is clearly a diagenetic boundary and younger than the true first appearance of the name species. This conclusion is supported by the age of the diatom assemblage at this boundary (Ciesielski, unpublished). 
P. F. CIESIELSKI, P. HASSON, J. W. TURNER, JR.

Table 2. Hole 643A silicoflagellate abundances, occurrences, zones, and ages. Species listing in order of highest occurrences. Intraspecific variants are listed separately with diagnostic characteristics indicated in parentheses. The key to the abbreviations indicating morphologic characteristics is as follows: $w /$ = with, aw. = apical window, brs. = basal ring sides, sp. = basal ring spines, br. = basal ring, asym. = asymmetrical. See Table 3 for a listing of barren samples.

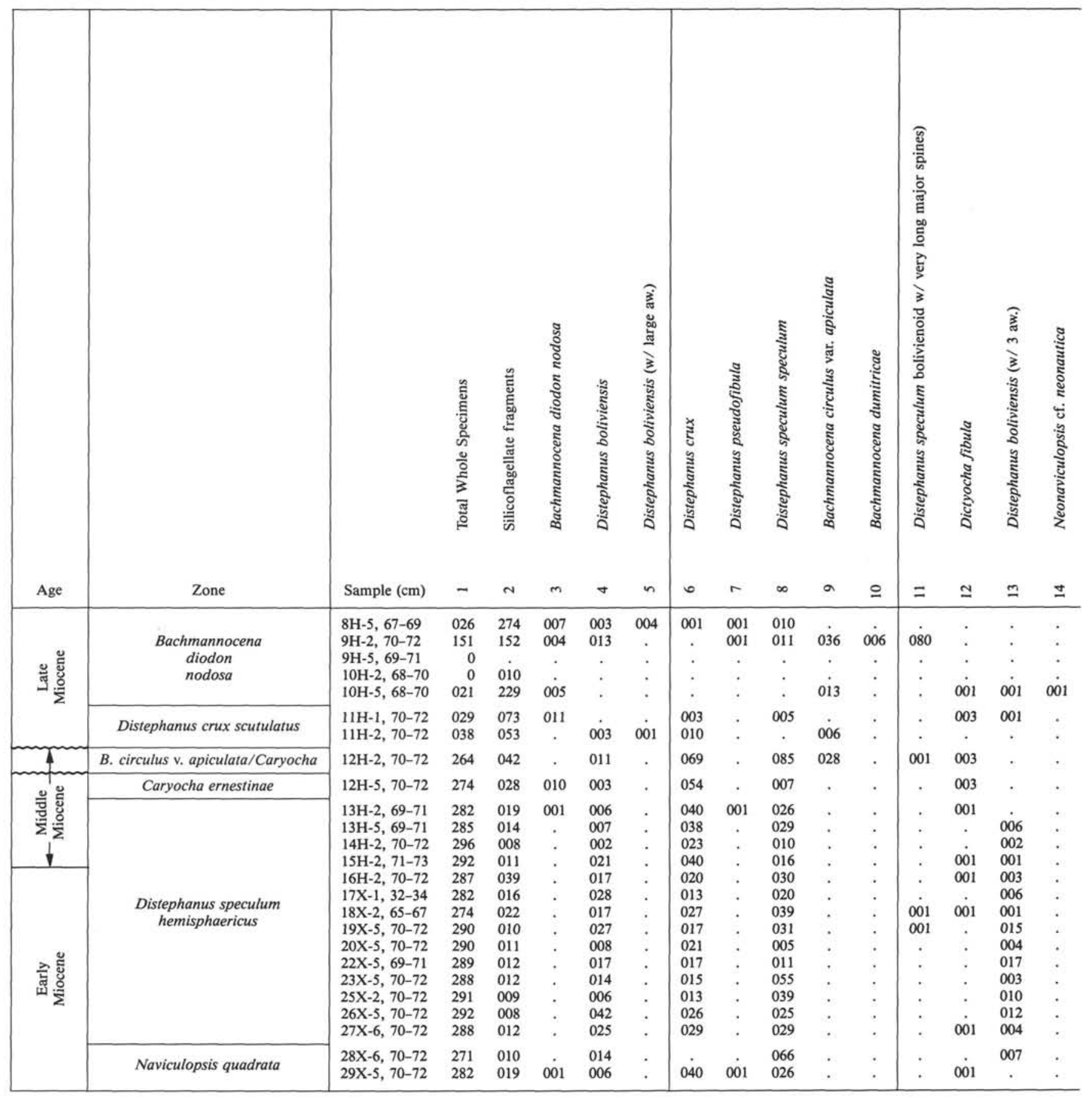

All examined samples from beneath the diagenetic boundary at $\sim 284$ mbsf were barren except for two samples examined onboard ship. Sections 104-643A-33X, CC and 104-643A-34X, CC contain three specimens of Distephanus crux s.l. and Ds. longispinus. These specimens may represent downhole contaminants and alone may not be used for an age designation.

\section{Site 644 (Tables 4 and 5)}

Ninety samples were examined from Hole 644A for their silicoflagellate content (Tables 4 and 5). Only the basal five sam- ples between 104-644A-32H-1, 70-72 cm and 104-644A-34H, $\mathrm{CC}$ had appreciable numbers of silicoflagellates (Table 4).

Ages of samples with silicoflagellates were estimated on the basis of an assumption of constant sedimentation rates between the paleomagnetic boundaries established by Bleil (this volume). Silicoflagellates are completely absent from sediments younger than the late Matuyama Chron $(<0.756 \mathrm{Ma})$. Only one specimen of Distephanus speculum speculum and a few unidentifiable silicoflagellate fragments occur between the last significant occurrence of the group in sediments of the upper Gauss Chro- 


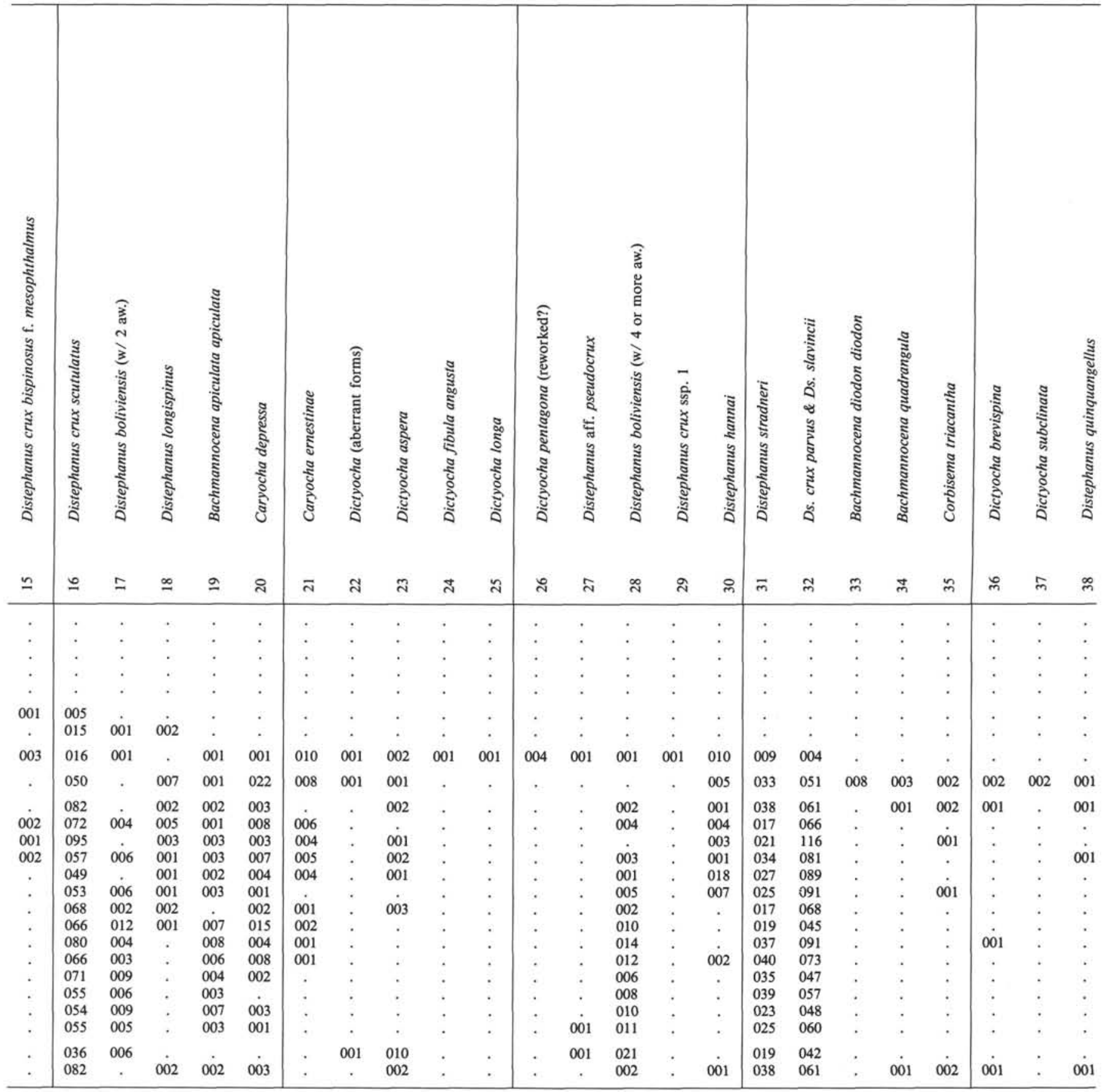

nozone (2.65 Ma) and the uppermost Matuyana Chronozone (0.756 Ma).

Sample 104-644A-32H-1, 70-72 cm is assigned an age of $2.65 \mathrm{Ma}$ and contains the youngest significant occurrence of silicoflagellates. Fifty-three silicoflagellates and fragments were counted with fragments being almost as abundant as whole specimens. The assemblage consists of rare to sparse occurrences of Dictyocha fibula, Distephanus frugalis, Ds. sulcatus, and subspecies of the Ds. boliviensis, and Ds. speculum groups.

Samples 104-644A-32H-3, 70-72 cm (2.69 Ma) and -644A$33 \mathrm{H}-1,70-72 \mathrm{~cm}(2.73 \mathrm{Ma})$ contain only fragments and a few specimens of Distephanus boliviensis boliviensis and Ds. speculum minutus. Sample 104-644A-34H-2, 70-72 cm (2.78 Ma) contains common silicoflagellates and fragments with a relatively diverse assemblage including Distephanus sulcatus and a variety of subspecies and morphotypes of Ds. crux, Ds. boliviensis, and Ds. speculum. The greatest occurrence of silicoflagellates in Hole 644A occurs in the basal Sample 104-644A-34H-5, $70-72 \mathrm{~cm}$ where they are abundant. This lowermost sample contains Distephanus septenarius, Ds. frugalis, and numerous subspecies and morphotypes of Distephanus boliviensis and Ds. crux. 
Table 2 (continued).

\begin{tabular}{|c|c|c|c|c|c|c|c|c|c|c|c|c|c|c|c|c|}
\hline & & & 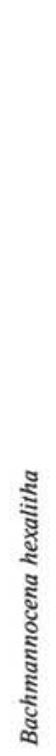 & 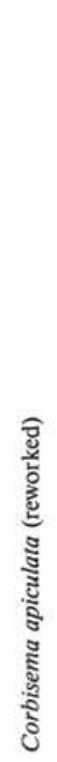 & 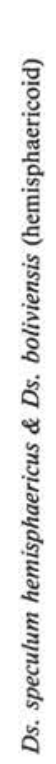 & 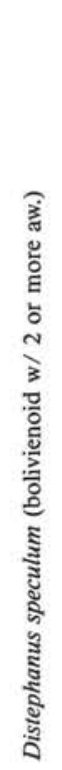 & $\begin{array}{l}\overline{0} \\
\text { के } \\
\text { हैं } \\
\text { है } \\
\text { : }\end{array}$ & 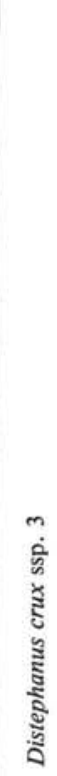 & 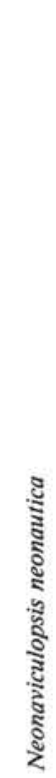 & 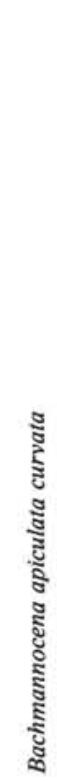 & 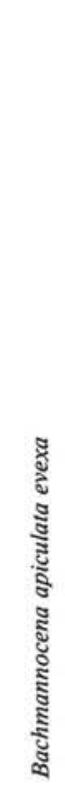 & 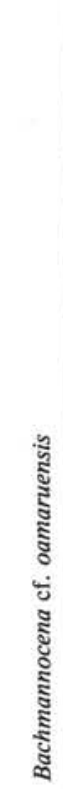 & 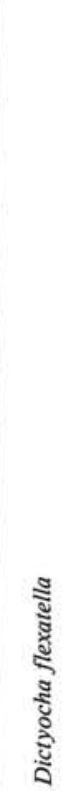 & 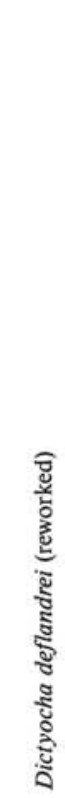 & 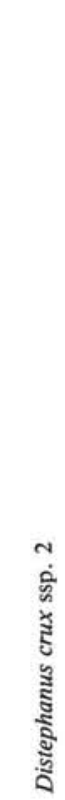 & 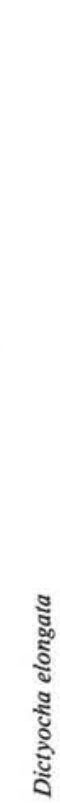 \\
\hline Age & Zone & Sample (cm) & ले & ९ & $\bar{\nabla}$ & F & ? & 寸 & 7 & $\stackrel{8}{+2}$ & $F$ & $\stackrel{\infty}{+}$ & $g$ & ஜ & $\bar{n}$ & $\approx$ \\
\hline \multirow{5}{*}{ すั } & & $8 \mathrm{H}-5,67-69$ & . & . & . & . & . & . & . & . & . & . & . & . & . & . \\
\hline & $\begin{array}{l}\text { Bachmannocena } \\
\text { diodon }\end{array}$ & $\begin{array}{l}9 \mathrm{H}-2,70-72 \\
9 \mathrm{H}-5,69-71\end{array}$ & · & . & . & · & . & . & . & . & - & . & . & . & . & · \\
\hline & nodosa & $10 \mathrm{H}-2,68-70$ & : & : & 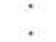 & $\dot{.}$ & $\dot{.}$ & $\dot{.}$ & $\dot{.}$ & $\dot{.}$ & $\dot{.}$ & $\dot{.}$ & : & : & $\dot{.}$ & $\dot{.}$ \\
\hline & & $10 \mathrm{H}-5,68-70$ & . & . & . & . & . & . & . & . & - & . & . & . & . & . \\
\hline & Distephanus crux scutulatus & $\begin{array}{l}11 \mathrm{H}-1,70-72 \\
11 \mathrm{H}-2,70-72\end{array}$ & . & : & . & . & : & . & . & : & . & . & . & . & . & . \\
\hline 1 & B. circulus v. apiculata/Caryocha & $12 \mathrm{H}-2,70-72$ & . & . & . & . & . & . & . & . & . & . & . & . & . & . \\
\hline \multirow{4}{*}{ 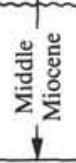 } & Caryocha ernestinae & $12 \mathrm{H}-5,70-72$ & . & . & . & . & . & - & . & . & . & . & . & . & . & . \\
\hline & \multirow{12}{*}{$\begin{array}{l}\text { Distephanus speculum } \\
\text { hemisphaericus }\end{array}$} & $13 \mathrm{H}-2,69-71$ & 001 & 001 & 007 & $\sin$ & . & . & . & . & . & . & . & . & . & . \\
\hline & & $13 \mathrm{H}-5,69-71$ & . & 002 & 012 & 002 & 001 & $\therefore$ & . & . & . & . & . & . & . & . \\
\hline & & $\begin{array}{l}14 \mathrm{H}-2,70-72 \\
15 \mathrm{H}-2,71-73\end{array}$ & : & $\cdot$ & 004 & $\begin{array}{l}002 \\
005\end{array}$ & 001 & 001 & 001 & · & $\cdot$ & • & . & . & . & . \\
\hline \multirow{11}{*}{ 즐 } & & $16 \mathrm{H}-2,70-72$ & : & 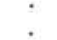 & 005 & 005 & $\therefore$ & 002 & . & 001 & 001 & 001 & 010 & • & - & $\dot{.}$ \\
\hline & & $17 \mathrm{X}-1,32-34$ & . & 001 & 004 & 008 & . & 001 & . & 002 & . & . & 001 & 001 & 004 & . \\
\hline & & $18 X-2,65-67$ & . & . & 007 & 005 & . & . & . & . & . & . & 001 & . & 009 & 001 \\
\hline & & $19 X-5,70-72$ & . & . & 001 & 014 & . & . & . & 004 & . & . & · & . & 002 & . \\
\hline & & $20 X-5,70-72$ & . & & 001 & 008 & . & - & . & 002 & . & . & $\therefore$ & . & & \\
\hline & & $\begin{array}{l}22 \mathrm{X}-5,69-71 \\
23 \mathrm{X}-5,70-72\end{array}$ & . & 001 & 002 & $\begin{array}{l}009 \\
023\end{array}$ & : & : & : & $\begin{array}{l}001 \\
001\end{array}$ & : & : & 002 & 001 & : & . \\
\hline & & $25 X-2,70-72$ & . & . & 003 & 052 & . & . & . & . & . & . & . & . & : & : \\
\hline & & $26 \mathrm{X}-5,70-72$ & . & . & 003 & 027 & . & . & . & 001 & . & . & . & . & . & . \\
\hline & & $27 X-6,70-72$ & & . & 003 & 035 & . & 001 & . & . & . & . & . & . & . & . \\
\hline & \multirow[t]{2}{*}{ Naviculopsis quadrata } & $28 \mathrm{X}-6,70-72$ & & & & 025 & . & . & . & . & 001 & . & - & . & . & . \\
\hline & & $29 X-5,70-72$ & 001 & 001 & 007 & . & . & - & . & . & . & . & . & . & . & . \\
\hline
\end{tabular}

The basal portion of Hole 644A containing silicoflagellates is assigned to the Distephanus speculum Zone, which is defined as the silicoflagellate-bearing interval above the last occurrence of Ds. jimlingii. Comparison of this assemblage with those at Sites 642 and 643 indicates that this zone is younger than the uppermost silicoflagellate-bearing horizons at those sites. Either erosion has removed this interval of the Gauss Chronozone from these other sites or the onset of glacial conditions ended silicoflagellate productivity earlier in the vicinity of Sites 642 and 643 .

\section{TAXONOMY}

In recent years there has been a proliferation of new silicoflagellate taxa. Many of these new taxa appear to have but mi- nor skeletal differences from previously existing taxa. Until such time as sufficent data have been accumulated on the abundance and stratigraphic ranges of skeletal morphotypes it will remain difficult to evaluate the the degree of species variability and revise the taxonomic standing of fossil silicoflagellates. It was our objective to contribute to the body of knowledge on silicoflagellate speices variability, with the long-term goal of major taxonomic revisions which will undoubtedly result in the combining of taxa as it is recognized that many are but intraspecific variants. With this objective in mind we have, for the most part, tabulated skeletal morphotypes separately. From our tables it is apparent that some species have rare and sporadic occurrences, suggesting that they may be intraspecific variants. In spite of these observations, we have taken a conservative point of view 
Table 2 (continued).

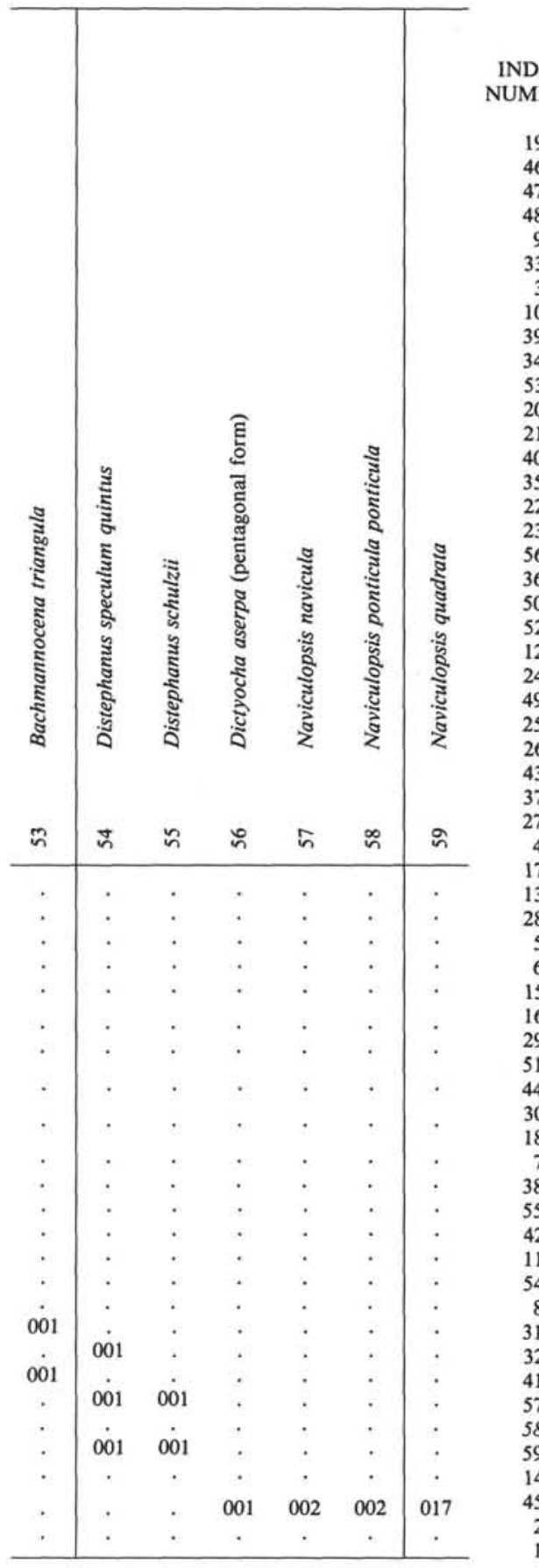

by deferring taxonomic revisions until these data may be compared with other ongoing studies of Neogene silicoflagellates from other regions. While this may result in some delay to much-needed taxomomic revisions, it is our intent not to add to an already considerable taxonomic confusion.

The following is a list of silicoflagellate taxa encountered in Leg 104 sequences from the Norwegian Sea. Also cited are references to the species authors, references to figures and plates herein, and appropriate remarks.

Bachmannocena apiculata apiculata (Schulz, 1928) Bukry, 1987.

B. apiculata curvata (Bukry, 1976c) Bukry, 1987 (Pl. 2, Figs. 1-3, figs. 5-6).
SPECIES LOCATION INDEX

Index numbers are the columns in which species appear.

\section{SPECIES}

Bachmannocena apiculata apiculata

Bachmannocena apiculata curvata

Bachmannocena apiculata evexa

Bachmannocena $\mathrm{cf}$. oamaruensis

Bachmannocena circulus var. apiculata

Bachmannocena diodon diodon

Bachmannocena diodon nodose

Bachmannocena dumitricae

Bachmannocena hexalitha

Bachmannocena quadrangula

Bachmannocena triangula

Caryocha depressa

Caryocha ernestinae

Corbisema apiculata (reworked)

Corbisema triacanthe

Dictyocha (aberrant forms)

Dictyocha aspera

Dictyocha aspera (pentagonal form)

Dictyocha brevispina

Dictyocha deflandrei (reworked)

Dictyocha elongato

Dictyocha fibula

Dictyocha fibula angusta

Dictyocha flexatella

Dictyocha longa

Dictyocha pentagona (reworked?)

Dictyocha sp. 1

Dictyocha subclinata

Distephanus aff. pseudocrux

Distephanus boliviensis

Distephanus boliviensis (w/ 2 aw.)

Distephanus boliviensis (w/ 3 aw.)

Distephanus boliviensis (w/ 4 or more aw.)

Distephanus boliviensis (w/ large aw.)

Distephanus crux

Distephanus crux bispinosus $\mathrm{f}$. mesophthalmus

Distephanus crux scutulatus

Distephanus crux ssp. 1

Distephanus crux ssp. 2

Distephanus crux ssp. 3

Distephanus hannai

Distephanus longispinus

Distephanus pseudofibula

Distephanus quanquangellus

Distephanus schulzii

Distephanus speculum (bolivienoid $\mathrm{w} / 2$ or more aw.)

Distephanus speculum (bolivienoid w/very long major spines)

Distephanus speculum quintus

Distephanus speculum speculum

Distephanus stradneri

Ds. crux parvus \& Ds. slavincii

Ds. speculum hemisphaericus \& Ds. boliviensis (hemisphaericoid)

Naviculopsis navicula

Naviculopsis ponticula ponticula

Naviculopsis quadrata

Neonaviculopsis $\mathrm{cf}$. neonautica

Neonaviculopsis neonautica

Silicoflagellate fragments

Total Whole Specimens

Remarks. The amount of indentation of the shorter side is highly variable. Specimens in Pl. 2, Figs. 4 and 5 show no appreciable indentation but have an isosocles ring and are associated with normal specimens of $B$. apiculata curvata.

B. apiculata evexa (Bukry, 1985) Bukry, 1987 (Pl. 2, Fig. 7).

B. apiculata glabra (Schulz, 1928) Bukry, 1978b (Pl. 2, Fig. 4).

B. apiculata inflata Bukry, 1978c (Pl. 2, Figs. 9, 12).

B. circulus var. apiculata (Lemmermann, 1901) Bukry, 1987 (Pl. 1, Figs. $1-2)$.

B. diodon borderlandensis Bukry, 1981a (Pl. 2, Fig. 11).

B. diodon diodon (Ehrenberg, 1844) Locker, 1974 (Pl. 3, Fig. 1).

B. diodon nodosa (Bukry, 1978c) Bukry, 1987 (Pl. 1, Figs 3-9).

B. dumitricae (Perch-Nielsen, 1975) Bukry, 1987. 
Table 3. Samples from the upper Eocene-lower Miocene, Pliocene, and Quaternary of Hole 643A which are barren of silicoflagellates.

\begin{tabular}{|c|c|}
\hline & \\
\hline & \\
\hline $104-643 \mathrm{~A}-2 \mathrm{H}-2,70-72 \mathrm{~cm}$ & 104-643A-39X \\
\hline $104-643 \mathrm{~A}-2 \mathrm{H}-5,70-72 \mathrm{~cm}$ & $104-643 \mathrm{~A}$ \\
\hline $57 \mathrm{~cm}$ & 104. \\
\hline $104-643 \mathrm{~A}-3 \mathrm{H}-5,65-67 \mathrm{~cm}$ & $104-643 A-44 X-2,70$ \\
\hline $104-643 \mathrm{~A}-4 \mathrm{H}-2,68-70 \mathrm{~cm}$ & $104-643 \mathrm{~A}-45 \mathrm{X}-2,70-72 \mathrm{~cm}$ \\
\hline $104-643 \mathrm{~A}-4 \mathrm{H}-5,70-72 \mathrm{~cm}$ & $104-643 \mathrm{~A}-46 \mathrm{X}-2,70-72 \mathrm{~cm}$ \\
\hline $104-643 \mathrm{~A}-5 \mathrm{H}-2,66-68 \mathrm{~cm}$ & $104-643 \mathrm{~A}-46 \mathrm{X}-5,70-72 \mathrm{~cm}$ \\
\hline $104-643 \mathrm{~A}-5 \mathrm{H}-5,69-71 \mathrm{~cm}$ & $7 \mathrm{X}-2,70-72 \mathrm{~cm}$ \\
\hline $104-643 \mathrm{~A}-6 \mathrm{H}-2, ?$ & $104-643 \mathrm{~A}-47 \mathrm{X}-5,70-72 \mathrm{~cm}$ \\
\hline $104-6$ & $104-$ \\
\hline 104-643. & $104-6$ \\
\hline $104-643 \mathrm{~A}-7$ & $104-643$ \\
\hline $104-64$ & $104-643$ \\
\hline 104 & $104-6$ \\
\hline $104-6$ & $104-6$ \\
\hline $104-643 \mathrm{~A}-32 \mathrm{X}-2,70-72 \mathrm{~cm}$ & $104-643 \mathrm{~A}-51 \mathrm{X}-5,70-72 \mathrm{~cm}$ \\
\hline $104-643 \mathrm{~A}-33 \mathrm{X}-2,70-72 \mathrm{~cm}$ & $104-643 \mathrm{~A}-52 \mathrm{X}-2,69-71 \mathrm{~cm}$ \\
\hline $104-643 \mathrm{~A}-34 \mathrm{X}-2,70-72 \mathrm{~cm}$ & $104-643 \mathrm{~A}-52 \mathrm{X}-5,69-71 \mathrm{~cm}$ \\
\hline $104-643 \mathrm{~A}-36 \mathrm{X}-2,65-67 \mathrm{~cm}$ & $104-643 \mathrm{~A}-53 \mathrm{X}-2,70-72 \mathrm{~cm}$ \\
\hline & $104-643 \mathrm{~A}-53 \mathrm{X}-5,70-72 \mathrm{~cm}$ \\
\hline
\end{tabular}

B. eliiptica (Ehrenberg, 1844) Bukry, 1987.

B. hexalitha (Bukry, 1981b) Bukry, 1987.

B. oamaruensis (Schulz, 1928) Bukry, 1987.

B. ovata (Bukry, 1978c) Bukry, 1987 (Pl. 2, Fig. 8).

B. quadrangula (Ehrenberg ex Haeckel, 1887) Bukry, 1987 (Pl. 3, Fig. 2).

B. schulzii (Martini et Müller, 1976) Bukry 1987 (Pl. 2, Fig. 10).

B. triangula (Ehrenberg, 1839) Locker, 1974.

B. sp. (Pl. 3, Figs. 4-5).

Genus Caryocha Bukry et Monechi, 1985.

Remarks. We follow the practice of Bukry and Monechi (1985) of not recognizing the genus Cannopilus and include phenotypic varieties with nonglobular and subdivided apical apparatus in Distephanus. The genus Caryocha has a more restrictive geologic range than taxa of Distephanus with a subdivided apical apparatus, the former only being a major component of the assemblage in the lower and middle Miocene. Caryocha is distinctive for its globular form, multiple apical windows, nearly equant basal spines, and a basal ring equal to, or less than, the diameter of the apical structure.

Caryocha depressa (Ehrenberg, 1854) Bukry et Monechi, 1985 (Pl. 6, Figs. 2-3, 5-6)

C. ernestinae (Backmann, 1962) Bukry et Monechi, 1985 (Pl. 6, Figs. 78).

C. cf. latifenestrata (Bachmann in Ichikawa et al., 1964) Bukry et Monechi, 1985.

Corbisema apiculata (Lemmermann, 1901) Hanna, 1931.

C. flexuosa (Stradner, 1961) Perch-Nielson, 1975.

C. triacantha (Ehrenberg, 1844) Bukry et Foster, 1973 (Pl. 8, Fig. 15).

C. sp. 1.

Remarks. Three-sided basal ring indented in the middle where lateral rods join the basal ring. Lateral rods join to form a small triangular apical window centered above the basal apparatus, possessing only two long basal spines at two corners of the basal apparatus.

Dictyocha angulata Bukry, 1982.

D. aspera (Lemmermann, 1901) Bukry et Foster, 1973.

D. brevispina (Lemmermann, 1901) Bukry, 1976a (Pl. 3, Fig. 3; Pl. 8, Fig. 12).

Remarks. Barless variants such as those found in Sample 104-642B-10H, CC were also noted in the lower Pliocene by Dumitrica (1973b) from Site 206 and by Bukry from Site 504 .

D. deflandrei Frenguelli (1940) ex Glezer, 1966.

D. elongata Glezer, 1960.
D. fibula Ehrenberg, 1839.

D. flbula angusta Bukry, 1976b.

D. flexatella (Bukry, 1979) Bukry, 1985.

D. hexacantha Schulz, 1928.

D. longa Bukry, 1982.

Remarks. A few of the specimens have an apical bar slightly out of alignment with the major axis.

D. pentagona (Schulz, 1928) Bukry and Foster, 1973 (Pl. 8, Fig. 13).

D. pulchella var. inflata Bukry, 1985 (Pl. 8, Fig. 14).

D. quadria (Mandra, 1969) Martini et Müller, 1976 (PI. 7, Fig. 15).

D. subclinata Bukry, 1981a.

D. sp. 1

Remarks. Equal-sided basal ring with five or six sides, basal ring sides strongly indented where an equal number of straight apical bars join the basal apparatus. Possessing relatively long and symmetrically aligned basal spines. Relatively rare in the lower to middle Miocene.

Distephanus bachmanni (Dumitrica, 1967) n. comb.

Dictyocha bachmanni Dumitrica, p. 1, Pl. 1, Figs. 1-17; Pl. 2, Figs. 1517.

Ds. boliviensis (Frenguelli, 1940) Bukry, 1973a (Pl. 5, Fig. 1).

Remarks. Bukry (1979) designated a lectotype from Frenguelli's type suite as Ds. boliviensis boliviensis which has relatively short equant spines and a single apical ring that is particularly common in the Pliocene and lower Quaternary. Spine length was not observed here, has a stable phenotype within the Ds. boliviensis and Ds. speculum stock. Herein all specimens are tabulated as Ds. boliviensis, regardless of spine length, so long as the basal spine lengths are equal.

Ds. boliviensis (cannopilean) (Pl. 5, Figs. 3-7).

Remarks. Cannopilean forms of Ds. boliviensis are considered to be those which have a multiwindowed apical apparatus but otherwise are similar to Ds. boliviensis, except they may possess more than six sides to the basal ring and longer basal spines than Ds. boliviensis boliviensis. The relatively flat apical apparatus may be comprised of two to seven or more apical windows which do not completely fill the intrabasal ring space. Not included in this designation are distinctive cannopilean forms which are tabulated separately (e.g., Ds. jimlingii and Ds. sulcatus). Cannopilean forms of Ds. boliviensis are identified in the tables as Ds. boliviensis followed by an abbreviated descriptor in parentheses and include the following morphotypes: with two apical windows; with three apical windows; with four or more apical windows. Reference to the tables reveals that cannopilean forms of Ds. boliviensis occurred most frequently during times of abundance of other species of Distephanus and Caryocha with a subdivided apical apparatus. The stratigraphic relation ship of these cannopilean forms to Ds. boliviensis suggests that they are intraspecific variants whose abundance was controlled by paleoceanographic conditions. Further taxonomic division based upon the number of apical windows is discouraged as there is no apparent stratigraphic significance to their occurrence.

Ds. boliviensis (cannopilean-irregular) (PI. 3, Figs. 6, 8-11).

Remarks. While photographing several core-catcher samples from Hole $643 \mathrm{~A}$, several specimens were encountered which are equant-spined and similar to Ds. boliviensis but have a highly variable apical appara tus. Specimens may exhibit wavy apical bars, small and large apical spines, extra lateral rods, and extra radial spines. Unusual paleoenvironmental conditions may have caused increased skeletal plasticity represented in these speciens.

Ds. boliviensis (hemisphaericoid) (Pl. 5, Fig. 8, Pl. 6, Fig. 1).

Remarks. Similar in all respects to Ds. boliviensis (cannopilean) except the multiwindowed apical apparatus is almost as wide as the basal ring; whereas, Ds. boliviensis (cannopilean) has a multiwindowed apical apparatus which is distinctly less than the width of the basal ring. Differs from Ds. speculum hemisphaericus by its near-equal basal spine length and larger basal ring. Ds. boliviensis (hemisphaeri- 
coid) and Ds. speculum hemisphaericus exhibit identical ranges in Site 642 and 643 , suggesting that they may intraspecific variations of the same taxa. Because of their identical stratigraphic range, both groups are tabulated together in Tables 1 and 2.

Ds. crux s.1. (Pl. 7, Figs. 4, 9)

Remarks. Distephanus crux is herein regarded as a group of subspecific taxa generally characterized by a tetragonal basal ring surmounted by an apical ring. Several subspecies are tabulated separately which conform to existing subspecies definitions. Other variants are tabulated as Ds. crux s. 1.

Ds. crux bispinosus Dumitrica, 1973.

Ds. crux bispinosus f. mesophthalmus (Ehrenberg, 1845) Locker et Martini, 1986.

Ds. crux parvus Bukry, 1982 (Pl. 7, Fig. 7).

Remarks. This subspecies was inadvertently tablulated together with $D s$. slavincii by one of us in our examination of Hole 643. Time constraints prevented a recounting of this hole, therefore, both taxa are listed collectively. Both taxa are listed separately in the occurrence chart of Holes $642 \mathrm{C}$ and 642D.

Ds. crux scutulatus Bukry, 1982 (Pl. 7, Figs. 5, 10).

Ds. crux ssp. 1 (Pl. 7, Fig. 11).

Remarks. Quadrate and scalloped basal ring, very small basal spines, large apical window, sometime with knobby ornamentation.

Ds. crux ssp. 2.

Remarks. Small and quadrate basal ring, very strongly indented where the lateral rods join the basal ring, giving the basal ring a wavy appearance. Accessory spines may be present at the juncture of the lateral rods with the basal ring.

Ds. crux ssp. 3

Remarks. Elongate basal ring with the maximum dimension approximately twice that of its minimum dimension. Distinguished by the presence of moderate length basal spines aligned with the major axis, and the absence of minor axis spines.

Ds. aff. fibula hexacantha n. comb. Dictyocha fibula f. hexacantha Frenguelli, 1935, pl. 1, Figs. 1-14.

Remarks. Four specimens were found in early Miocene Sample 104642D-6X-2, 125-127 cm, which have a close affinity to specimens described by Frenguelli from the Holocene of Gulfo San Matias, Argentina. Due to its hexagonal basal ring the species is reassigned to Distephanus.

Ds. frugalis (Bukry, 1975b) Bukry, 1979.

Ds. hannai (Bukry, 1975b) Bukry, 1979.

Ds. jimlingii (Bukry, 1975b) Bukry, 1979 (Pl. 4, Figs. 3-4).

Remarks. Most specimens follow the description of Bukry's (1979) Ds. jimlingii by having a regularly arranged apical apparatus with a rounded central opening surrounded by a cycle of five to seven openings. Occasional specimens have two central openings surrounded by a cycle of other openings (Pl. 4, Figs. 3-4).

Ds. jimlingii/Ds. sulcatus (Pl. 4, Figs. 5-7).

Remarks. A number of specimens were observed in the Pliocene of Hole 642C which exhibit morphologic characteristics intermediate between Ds. jimlingii and Ds. sulcatus and are tablulated as Ds. jimlingii/Ds. sulcatus. These intermediate forms first occur in the upper range of Ds. jimlingii and range concurrently with the lower range of Ds. sulcatus. Apical windows are less regularly arranged than in Ds. jimlingii and do not exhibit the size variation of Ds. sulcatus. Tubular elements of the lateral rods are not as narrow with respect to the basal ring as in Ds. sulcatus and often have hyaline areas (PI. 4, Figs. 6-7).
Ds. longispinus (Schulz, 1928) Bukry, 1979 (Pl. 7, Fig. 8).

Ds. polyactis (Ehrenberg, 1838) Dumitrica, 1973.

Ds. polyactis crassus Bukry, 1977 (P1. 6, Fig. 10)

Ds. pseudocrux (Schulz, 1928) Bukry, 1973b.

Ds. pseudofibula (Schulz, 1928) Bukry, 1976c.

Ds. quinquangellus Bukry et Foster, 1973 (Pl. 7, Figs. 12-14, 16).

Remarks. Pentagoanl forms assigned to this species may have arisen independantly from Distephanus speculum and Ds. boliviensis. Specimens with a small basal apparatus (Pl. 7, Fig. 13) and long basal spines are more common in association with Ds. speculum; whereas larger varieties are associated with common Ds. boliviensis.

Ds. quintus (Bukry and Foster, 1973) Bukry, 1981.

Ds. schauinslandii Lemmermann, 1901.

Ds. schultii n. comb. (Pl. 6, Fig. 4).

Cannopilus schulztii Deflandre in Bachmann and Ichikawa, 1962, p. 171. = Cannopilus cyrtoides Schulz, 1928, Fig. 65.

Ds. septenarius (Ehrenberg, 1844); Perch-Nielsen, 1975.

Ds. slavincii (Jerkovic, 1965) Bukry, 1973c (Pl. 7, Figs. 1-3).

Remarks. This subspecies was inadvertently tablulated together with $D s$. crux parvus by one of us in our examination of Hole 643. Time constraints prevented a recounting of this hole, therefore, both taxa are listed collectively. Both taxa are listed separately in the occurrence chart of Holes $642 \mathrm{C}$ and 642D.

Ds. speculum (bolivienoid).

Remarks. Silicoflagellates similar to Ds. boliviensis, but having two opposing spines with lengths in excess of the remainder of the basal ring spines, may not be classified with this species which has somewhat equant spine lengths. However, specimens similar to Ds. boliviensis, but having two long opposing spines are tabulated here as Ds. speculum (bolivienoid) pending a revision of the taxonomic status of Distephanus species by the authors.

Ds. speculum f. coronata Schulz, 1928 (Pl. 6, Fig. 12).

Ds. speculum hemisphaericus (Ehrenberg, 1844) Bukry 1975 emend. (Pl. 5, Fig. 9).

Remarks. Recent detailed quantitative analyses of silicoflagellates with multiple windowed apical structures by Shaw and Ciesielski (1983) and herein, reveal justification for emendation of this species. This taxon is emended to include forms with a six- to eight-sided basal ring similar to or slightly larger in size than $D$ s. speculum speculum, but distinctly smaller than $D$ s. boliviensis, with a relatively flat to slightly domed apical apparatus bearing four or more apical windows, which has a width almost as great as the basal apparatus. Supporting rods connecting the apical apparatus to the basal ring are indistinct because of the width of the apical apparatus. Apical windows may be arranged in any fashion, as there is no stratigraphic significance to particular arrangements. Apical windows may be irregularly arranged and sized. Basal accessory spines are usually present on the basal ring.

Ds. speculum giganteus Bukry, 1976c.

Ds. speculum minutus (Backmann in Ichikawa et al., 1967) Bukry, 1976b emend. Bukry, 1981a (PI. 6, Fig. 13).

Ds. speculum s.l. (Ehrenberg, 1839) Haeckel, 1887 (Pl. 4, Figs 1, 2, Pl. 6, Figs. 11, 14).

Ds. speculum triomata (Ehrenberg, 1845) Bukry, 1976a.

Ds. stradneri (Jerkovic, 1965) Bukry, 1978b (Pl. 7, Fig. 6).

Ds. sulcatus Bukry 1979 (Pl. 4, Figs. 8-10).

Remarks. Most specimens, such as those illustrated herein, have a basal ring which is not as sulcate as those illustrated by Bukry (1979). In other respects, those tabulated herein adhere to the original description of Bukry (1979).

Ds. trigonus Uchio, 1974.

Ds. cf. xenus Bukry, 1985.

Naviculopsis biapiculata (Lemmerman, 1901) Frenguelli, 1940.

N. constricta (Schulz, 1928) Bukry emend., in Barron, Bukry, and Poore, 1984 (Pl. 8, Fig. 11). 
Table 4. Leg 104, Hole 644A silicoflagellate abundances, occurrences, zones, and ages. Species listing in order of highest occurrences. Intraspecific variants are listed separately with diagnostic characteristics indicated in parentheses. The key to the abbreviations indicating morphologic characteristics is as follows: $\mathbf{w} /=$ with, aw. $=$ apical window, brs. $=$ basal ring sides, sp. = basal ring spines, br. = basal ring, asym. = asymmetrical. See Tables 3 and 5 for listings of barren samples.

\begin{tabular}{|c|c|c|c|c|c|c|c|c|c|c|c|c|c|c|c|c|c|c|c|c|c|c|c|c|c|c|c|}
\hline Sample $(\mathrm{cm})$ & 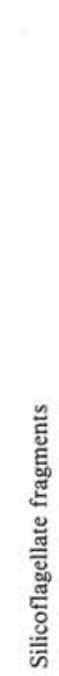 & 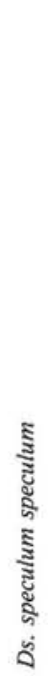 & 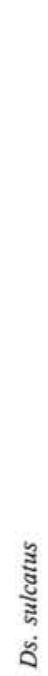 & 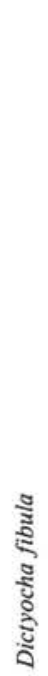 & 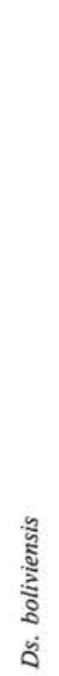 & 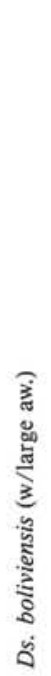 & 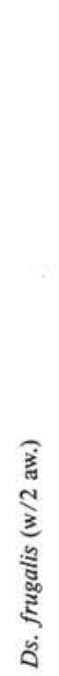 & 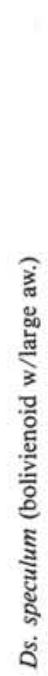 & 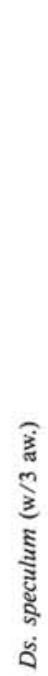 & 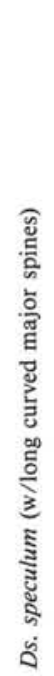 & 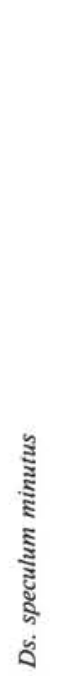 & 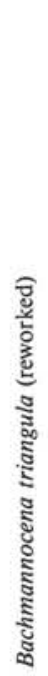 & 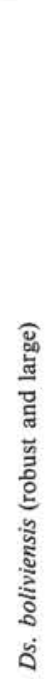 & 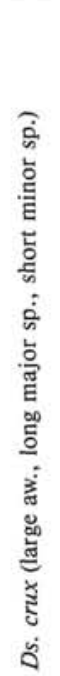 & 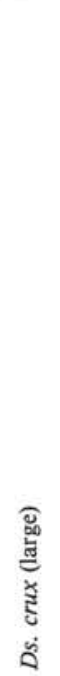 & 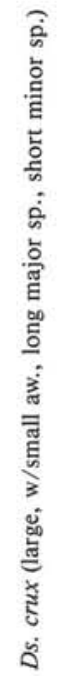 & 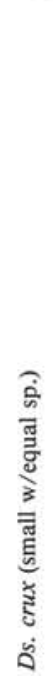 & 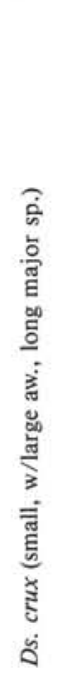 & 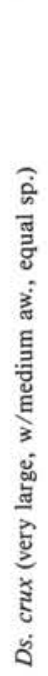 & 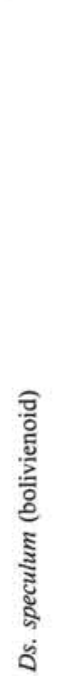 & 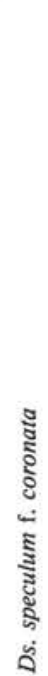 & 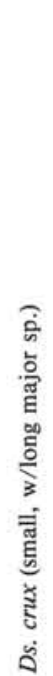 & 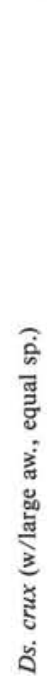 & 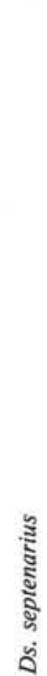 & 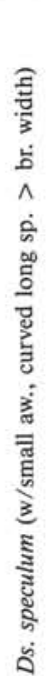 & 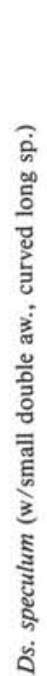 & 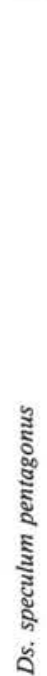 \\
\hline $1 \mathrm{H}-2,70-72$ & . & . & . & . & . & . & . & . & . & . & . & . & . & . & . & . & . & . & . & . & . & . & . & . & . & . & . \\
\hline 1H-5, 70-72 & . & . & . & . & . & . & . & . & . & . & . & . & . & . & . & . & . & . & . & . & . & . & . & . & . & . & . \\
\hline $2 \mathrm{H}-2,70-72$ & . & . & . & . & . & . & . & . & . & . & . & . & . & . & . & . & . & . & . & . & . & . & . & . & . & . & . \\
\hline $2 \mathrm{H}-5,56-58$ & . & . & . & . & . & . & . & . & . & . & . & . & . & . & . & . & . & . & . & . & . & . & . & . & . & . & . \\
\hline $3 \mathrm{H}-2,68-70$ & . & . & . & . & . & . & . & . & . & . & . & . & . & . & . & . & . & . & . & . & . & . & . & . & . & . & . \\
\hline $3 \mathrm{H}-5,68-70$ & . & . & . & . & . & . & . & . & . & . & . & . & . & . & . & . & . & . & . & . & . & . & . & . & . & . & . \\
\hline $4 \mathrm{H}-2,70-72$ & . & . & . & . & . & . & . & . & . & . & . & . & . & . & . & . & . & . & . & . & . & . & . & . & . & . & . \\
\hline $4 \mathrm{H}-5,70-72$ & . & . & . & . & . & . & . & . & . & . & . & . & . & . & . & . & . & . & . & . & . & . & . & . & . & . & . \\
\hline $5 \mathrm{H}-2,70-72$ & . & . & . & . & . & . & . & . & . & . & . & . & . & . & . & . & . & . & . & . & . & . & . & . & . & . & . \\
\hline $5 \mathrm{H}-5,70-72$ & . & . & . & . & . & . & . & . & . & . & . & . & . & . & . & . & . & . & . & . & . & . & . & . & . & . & . \\
\hline $6 \mathrm{H}-2,69-71$ & . & . & . & . & . & . & . & . & . & . & . & . & . & . & . & . & . & . & . & . & . & . & . & . & . & . & . \\
\hline $6 \mathrm{H}-5,69-71$ & . & . & . & . & . & . & . & . & . & . & . & . & . & . & . & . & . & . & . & . & . & . & . & . & . & . & . \\
\hline $7 \mathrm{H}-2,70-72$ & . & . & . & . & . & . & . & . & . & . & . & . & . & . & . & . & . & . & . & . & . & . & . & . & . & . & . \\
\hline $7 \mathrm{H}-4,70-72$ & . & . & . & . & . & . & . & . & . & . & . & . & . & . & . & . & . & . & . & . & . & . & . & . & . & . & . \\
\hline $8 \mathrm{H}-2,70-72$ & . & . & . & . & . & . & . & . & . & . & . & . & . & . & . & . & . & . & . & . & . & . & . & . & . & . & . \\
\hline $8 \mathrm{H}-5,56-58$ & . & . & . & . & . & . & . & . & . & . & . & . & . & . & . & . & . & . & . & . & . & . & . & . & . & . & . \\
\hline $9 \mathrm{H}-2,70-72$ & . & . & . & . & . & . & . & . & . & . & . & . & . & . & . & . & . & . & . & . & . & . & . & . & . & . & . \\
\hline $9 \mathrm{H}-5,70-72$ & . & . & . & . & . & . & . & . & . & . & . & . & . & . & . & . & . & . & . & . & . & . & . & . & . & . & . \\
\hline $9 \mathrm{H}, \mathrm{CC}$ & . & . & . & . & . & . & . & . & . & . & . & . & . & . & . & . & . & . & . & . & . & . & . & . & . & . & . \\
\hline $10 \mathrm{H}-2,55-57$ & . & . & . & . & . & . & . & . & . & . & . & . & . & . & . & . & . & . & . & . & . & . & . & . & . & . & . \\
\hline $10 \mathrm{H}-2,84-86$ & . & . & . & . & . & . & . & . & . & . & . & . & . & . & . & . & . & . & . & . & . & . & . & . & . & . & . \\
\hline $10 \mathrm{H}-2,70-72$ & 001 & . & . & . & . & . & . & . & . & . & . & . & . & . & . & . & . & . & . & . & . & . & . & . & . & . & . \\
\hline $10 \mathrm{H}-5,70-72$ & . & . & . & . & . & . & . & . & . & . & . & . & . & . & . & . & . & . & . & . & . & . & . & . & . & . & . \\
\hline $10 \mathrm{H}, \mathrm{CC}$ & . & . & . & . & . & . & . & . & . & . & . & . & . & . & . & . & . & . & . & . & . & . & . & . & . & . & . \\
\hline $11 \mathrm{H}-2,70-72$ & . & . & . & . & . & . & . & . & . & . & . & . & . & . & . & . & . & . & . & . & . & . & . & . & . & . & . \\
\hline $11 \mathrm{H}-5,70-72$ & . & . & . & . & . & . & . & . & . & . & . & . & . & . & . & . & . & . & . & . & . & . & . & . & . & . & . \\
\hline $11 \mathrm{H}, \mathrm{CC}$ & . & . & . & . & . & . & . & . & . & . & . & . & . & . & . & . & . & . & . & . & . & . & . & . & . & . & . \\
\hline $12 \mathrm{H}-2,70-72$ & . & . & . & . & . & . & . & . & . & . & . & . & . & . & . & . & . & . & . & . & . & . & . & . & . & . & . \\
\hline $12 \mathrm{H}-5,70-72$ & . & . & . & . & . & . & . & . & . & . & . & . & . & . & . & . & . & . & . & . & . & . & . & . & . & . & . \\
\hline $12 \mathrm{H}, \mathrm{CC}$ & . & . & . & . & . & . & . & . & . & . & . & . & . & . & . & . & . & . & . & . & . & . & . & . & . & . & . \\
\hline $13 \mathrm{H}-2,70-72$ & . & . & . & . & . & . & . & . & . & . & . & . & . & . & . & . & . & . & . & . & . & . & . & . & . & . & . \\
\hline $13 \mathrm{H}-5,70-72$ & . & . & . & . & . & . & . & . & . & . & . & . & . & . & . & . & . & . & . & . & . & . & . & . & . & . & . \\
\hline $13 \mathrm{H}, \mathrm{CC}$ & . & . & . & . & . & . & . & . & . & . & . & . & . & . & . & . & . & . & . & . & . & . & . & . & . & . & . \\
\hline
\end{tabular}




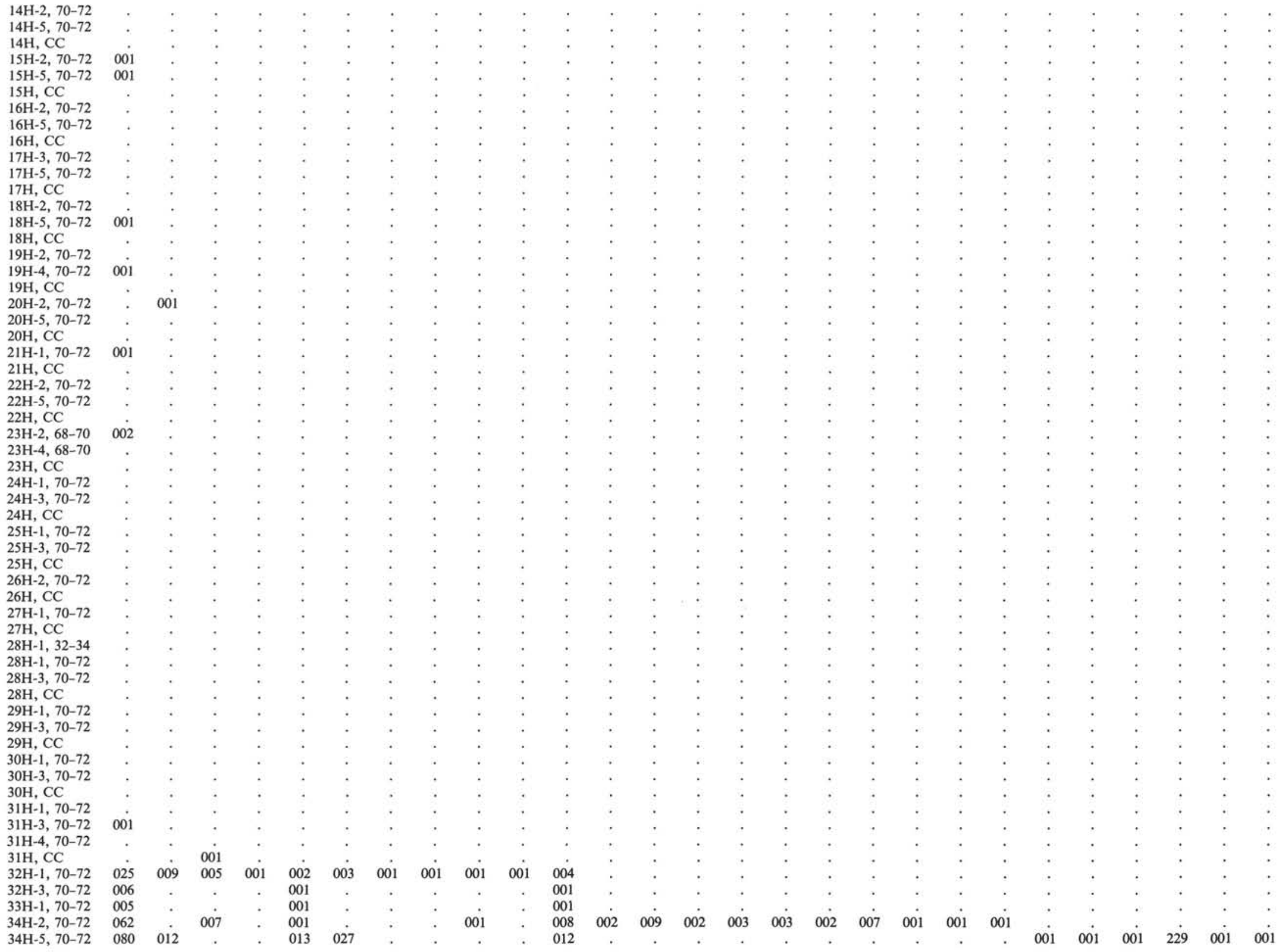


Table 5. Samples from the Pliocene-Quaternary of Hole 644A which are barren of silicoflagellates.

\begin{tabular}{ll}
\hline $104-644 \mathrm{~A}-1 \mathrm{H}-2,70-72 \mathrm{~cm}$ & $104-644 \mathrm{~A}-16 \mathrm{H}, \mathrm{CC}$ \\
$104-644 \mathrm{~A}-1 \mathrm{H}-5,70-72 \mathrm{~cm}$ & $104-644 \mathrm{~A}-17 \mathrm{H}-3,70-72 \mathrm{~cm}$ \\
$104-644 \mathrm{~A}-2 \mathrm{H}-2,70-72 \mathrm{~cm}$ & $104-644 \mathrm{~A}-17 \mathrm{H}-5,70-72 \mathrm{~cm}$ \\
$104-644 \mathrm{~A}-2 \mathrm{H}-5,56-58 \mathrm{~cm}$ & $104-644 \mathrm{~A}-17 \mathrm{H}, \mathrm{CC}$ \\
$104-644 \mathrm{~A}-3 \mathrm{H}-2,68-70 \mathrm{~cm}$ & $104-644 \mathrm{~A}-18 \mathrm{H}-2,70-72 \mathrm{~cm}$ \\
$104-644 \mathrm{~A}-3 \mathrm{H}-5,68-70 \mathrm{~cm}$ & $104-644 \mathrm{~A}-18 \mathrm{H}, \mathrm{CC}$ \\
$104-644 \mathrm{~A}-4 \mathrm{H}-2,70-72 \mathrm{~cm}$ & $104-644 \mathrm{~A}-19 \mathrm{H}-2,70-72 \mathrm{~cm}$ \\
$104-644 \mathrm{~A}-4 \mathrm{H}-5,70-72 \mathrm{~cm}$ & $104-644 \mathrm{~A}-19 \mathrm{H}, \mathrm{CC}$ \\
$104-644 \mathrm{~A}-5 \mathrm{H}-2,70-72 \mathrm{~cm}$ & $104-644 \mathrm{~A}-20 \mathrm{H}-5,70-72 \mathrm{~cm}$ \\
$104-644 \mathrm{~A}-5 \mathrm{H}-5,70-72 \mathrm{~cm}$ & $104-644 \mathrm{~A}-20 \mathrm{H}, \mathrm{CC}$ \\
$104-644 \mathrm{~A}-6 \mathrm{H}-2,69-71 \mathrm{~cm}$ & $104-644 \mathrm{~A}-21 \mathrm{H}, \mathrm{CC}$ \\
$104-644 \mathrm{~A}-6 \mathrm{H}-5,69-71 \mathrm{~cm}$ & $104-644 \mathrm{~A}-22 \mathrm{H}-2,70-72 \mathrm{~cm}$ \\
$104-644 \mathrm{~A}-7 \mathrm{H}-2,70-72 \mathrm{~cm}$ & $104-644 \mathrm{~A}-22 \mathrm{H}-5,70-72 \mathrm{~cm}$ \\
$104-644 \mathrm{~A}-7 \mathrm{H}-4,70-72 \mathrm{~cm}$ & $104-644 \mathrm{~A}-22 \mathrm{H}, \mathrm{CC}$ \\
$104-644 \mathrm{~A}-8 \mathrm{H}-2,70-72 \mathrm{~cm}$ & $104-644 \mathrm{~A}-23 \mathrm{H}-4,68-70 \mathrm{~cm}$ \\
$104-644 \mathrm{~A}-8 \mathrm{H}-5,56-58 \mathrm{~cm}$ & $104-644 \mathrm{~A}-23 \mathrm{H}, \mathrm{CC}$ \\
$104-644 \mathrm{~A}-9 \mathrm{H}-2,70-72 \mathrm{~cm}$ & $104-644 \mathrm{~A}-24 \mathrm{H}-1,70-72 \mathrm{~cm}$ \\
$104-644 \mathrm{~A}-9 \mathrm{H}-5,70-72 \mathrm{~cm}$ & $104-644 \mathrm{~A}-24 \mathrm{H}-3,70-72 \mathrm{~cm}$ \\
$104-644 \mathrm{~A}-9 \mathrm{H}, \mathrm{CC}$ & $104-644 \mathrm{~A}-24 \mathrm{H}, \mathrm{CC}$ \\
$104-644 \mathrm{~A}-10 \mathrm{H}-2,55-57 \mathrm{~cm}$ & $104-644 \mathrm{~A}-25 \mathrm{H}-1,70-72 \mathrm{~cm}$ \\
$104-644 \mathrm{~A}-10 \mathrm{H}-2,84-86 \mathrm{~cm}$ & $104-644 \mathrm{~A}-25 \mathrm{H}-3,70-72 \mathrm{~cm}$ \\
$104-644 \mathrm{~A}-10 \mathrm{H}-5,70-72 \mathrm{~cm}$ & $104-644 \mathrm{~A}-25 \mathrm{H}, \mathrm{CC}$ \\
$104-644 \mathrm{~A}-10 \mathrm{H}, \mathrm{CC}$ & $104-644 \mathrm{~A}-26 \mathrm{H}-2,70-72 \mathrm{~cm}$ \\
$104-644 \mathrm{~A}-11 \mathrm{H}-2,70-72 \mathrm{~cm}$ & $104-644 \mathrm{~A}-26 \mathrm{H}, \mathrm{CC}$ \\
$104-644 \mathrm{~A}-11 \mathrm{H}-5,70-72 \mathrm{~cm}$ & $104-644 \mathrm{~A}-27 \mathrm{H}-1,70-72 \mathrm{~cm}$ \\
$104-644 \mathrm{~A}-11 \mathrm{H}, \mathrm{CC}$ & $104-644 \mathrm{~A}-27 \mathrm{H}, \mathrm{CC}$ \\
$104-644 \mathrm{~A}-12 \mathrm{H}-2,70-72 \mathrm{~cm}$ & $104-644 \mathrm{~A}-28 \mathrm{H}-1,32-34 \mathrm{~cm}$ \\
$104-644 \mathrm{~A}-12 \mathrm{H}-5,70-72 \mathrm{~cm}$ & $104-644 \mathrm{~A}-28 \mathrm{H}-1,70-72 \mathrm{~cm}$ \\
$104-644 \mathrm{~A}-12 \mathrm{H}, \mathrm{CC}$ & $104-644 \mathrm{~A}-28 \mathrm{H}-3,70-72 \mathrm{~cm}$ \\
$104-644 \mathrm{~A}-13 \mathrm{H}-2,70-72 \mathrm{~cm}$ & $104-644 \mathrm{~A}-28 \mathrm{H}, \mathrm{CC}$ \\
$104-644 \mathrm{~A}-13 \mathrm{H}-5,70-72 \mathrm{~cm}$ & $104-644 \mathrm{~A}-29 \mathrm{H}-1,70-72 \mathrm{~cm}$ \\
$104-644 \mathrm{~A}-13 \mathrm{H}, \mathrm{CC}$ & $104-644 \mathrm{~A}-29 \mathrm{H}-3,70-72 \mathrm{~cm}$ \\
$104-644 \mathrm{~A}-14 \mathrm{H}-2,70-72 \mathrm{~cm}$ & $104-644 \mathrm{~A}-29 \mathrm{H}, \mathrm{CC}$ \\
$104-644 \mathrm{~A}-14 \mathrm{H}-5,70-72 \mathrm{~cm}$ & $104-644 \mathrm{~A}-30 \mathrm{H}-1,70-72 \mathrm{~cm}$ \\
$104-644 \mathrm{~A}-14 \mathrm{H}, \mathrm{CC}$ & $104-644 \mathrm{~A}-30 \mathrm{H}-3,70-72 \mathrm{~cm}$ \\
$104-644 \mathrm{~A}-15 \mathrm{H}, \mathrm{CC}$ & $104-644 \mathrm{~A}-30 \mathrm{H}, \mathrm{CC}$ \\
$104-644 \mathrm{~A}-16 \mathrm{H}-2,70-72 \mathrm{~cm}$ & $104-644 \mathrm{~A}-31 \mathrm{H}-1,70-72 \mathrm{~cm}$ \\
$104-644 \mathrm{~A}-16 \mathrm{H}-5,70-72 \mathrm{~cm}$ & $104-644 \mathrm{~A}-31 \mathrm{H}-4,70-72 \mathrm{~cm}$ \\
&
\end{tabular}

N. iberica Deflandre, 1950 (Pl. 8, Fig. 7).

N. lata (Deflandre, 1932) Bukry, 1982 (Pl. 8, Figs. 1-3, 6).

N. navicula (Ehrenberg, 1840) Deflandre, 1950 (Pl. 8, Fig. 9).

N. ponticula ponticula (Ehrenberg, 1844) Bukry, 1982 (Pl. 8, Figs. 4-5).

N. ponticula spinosa Bukry, 1982.

N. punctilia Perch-Nielsen, 1976.

N. quadrata (Ehrenberg, 1844) Locker (1974).

N. sp. (Pl. 8, Figs. 8, 10).

Remarks. These specimens may possibly be intraspecific variations of N. navicula.

Neonaviculopsis neonautica (Bukry, 1981) Locker et Martini, 1986.

\section{ACKNOWLEDGMENTS}

We thank Susan M. Case for editing of the manuscript and many long hours spent entering species data and generating species range charts by computer. The National Science Foundation and the Joint Oceanographic Institutions, Inc. are thanked for the sponsorship of the shipboard participation of PFC on the Ocean Drilling Program Leg 104. These same institutions are also thanked for their postcruise financial support of this research through the Texas A\&M Research Foundation/United States Science Program award \#76056 to PFC.

Hsin Yi Ling and an anonymous reviewer are thanked for their critical review of the manuscript. Other useful comments and suggestions were made by E. Taylor and J. Thiede.

\section{REFERENCES}

Bachmann, A., 1962. Eine neu entdeckte Silicoflagellidenart: Cannopilus ernestinae Bachmann, nov. spec. Mikrokosmos, 51: 255.

Barron, J. A., 1980. Lower Miocene to Quaternary diatom biostratigraphy of Leg 57, off northeastern Japan, Deep Sea Drilling Project. Init. Repts. DSDP, 56, 57, Pt. 2: Washington (U.S. Govt. Printing Office), 641-685.
1985. Miocene to Holocene planktic diatoms. In Bolli, H. M., Saunders, J. B., and Perch-Nielsen, K. (Eds.), Plankton Stratigraphy: Cambridge (Cambridge University Press), 811-846.

Berggren, W. A., Kent, D. V., Flynn, J. J., and Van Couvering, J. A., 1985. Cenozoic geochronology. Geol. Soc. Am. Bull., 96:14071418.

Bukry, D., 1973a. Coccolith and silicoflagellate stratigraphy, Deep Sea Drilling Project Leg 18, eastern North Pacific. In Kulm, L. D., von Huene, R., et al., Init. Repts. DSDP, 18: Washington (U.S. Govt. Printing Office), $817-831$.

1973b. Coccoliths and silicoflagellates from Deep Sea Drilling Project Leg 19, North Pacific Ocean and Bering Sea. In Creager, J. S., Scholl, D. W., et al., Init. Repts. DSDP, 19: Washington (U.S. Govt. Printing Office), 857-867.

1975a. Silicoflagellate and coccolith stratigraphy, Deep Sea Drilling Project Leg 29. In Kennett, J. P., Houtz, R. E., et al., Init. Repts. DSDP, 29: Washington (U.S. Govt. Printing Office), 845872.

1975b. Coccolith and silicoflagellate stratigraphy, northwest Pacific Ocean, Deep Sea Drilling Project Leg 32. In Larson, R. L., Moberly, R., et al., Init. Repts., DSDP, 32: Washington (U.S. Govt. Printing Office), 677-701.

1976a. Silicoflagellate and coccolith stratigraphy, southeastern Pacific Ocean, Deep Sea Drilling Project Leg 34. In Yeats R. S., Hart, S. R., et al., Init. Repts. DSDP, 34: Washington (U.S. Govt. Printing Office), 715-735.

1976b. Cenozoic silicoflagellate and coccolith stratigraphy, South Atlantic Ocean, Deep Sea Drilling Project Leg 36. In Hollister, C. D., Craddock, C., Init. Repts. DSDP, 35: Washington (U.S. Govt. Printing Office), 885-917.

1976c. Silicoflagellate and coccolith stratigraphy, NorwegianGreenland Sea, Deep Sea Drilling Project Leg 38. In Talwani, M., Udintsev, G., et al., Init. Repts. DSDP, 38: Washington (U.S. Govt. Printing Office), 843-855.

1977. Coccolith and silicoflagellate stratigraphy, central and North Atlantic, Deep Sea Drilling Project Leg 37. In Aumento, F., Melson, W. G., et al., Init. Repts. DSDP, 37: Washington (U.S. Govt. Printing Office), 907-927.

,1978a. Cenozoic silicoflagellate and coccolith stratigraphy, southeastern Atlantic Ocean, Deep Sea Drilling Project Leg 40. In Bolli, H. M., Ryan, W. B. F., et al., Init. Repts. DSDP, 40: Washington (U.S. Govt. Printing Office), 635-639.

1978b. Cenozoic silicoflagellate and coccolith stratigraphy, northwestern Atlantic Ocean, Deep Sea Drilling Project Leg 43. In Benson, W. E., Sheridan, R. E., et al., Init. Repts. DSDP, 44: Washington (U.S. Govt. Printing Office), 775-805.

1978c. Cenozoic coccolith, silicoflagellate, and diatom stratigraphy, Deep Sea Drilling Project Leg 44. In Benson, W. E., Sheridan, R. E., et al., Init. Repts. DSDP, 44: Washington (U.S. Govt. Printing Office), $807-863$.

1979. Comments on opal phytoliths and stratigraphy of Neogene silicoflagellates and coccoliths at Deep Sea Drilling Project Site 397 off northwest Africa. In Luyendyk, B. P., Cann, J. R., et al., Init. Repts. DSDP, 49: Washington (U.S. Govt. Printing Office), 977-1009.

1981a. Pacific Coast silicoflagellates, Deep Sea Drilling Project Leg 63. In Yeats, R. S., Haq, B. U., et al., Init. Repts. DSDP, 63: Washington (U.S. Govt. Printing Office), 539-557.

1981b. Synthesis of silicoflagellate stratigraphy for Maestrichtian to Quaternary marine sediment. Soc. Econ. Paleontol. Mineral. Spec. Publ., 32:433-444.

, 1982. Cenozoic silicoflagellates from offshore Guatemala, Deep Sea Drilling Project Site 495. In Aubouin, J., von Huene, R., et al.,Init. Repts. DSDP, 67: Washington (U.S. Govt. Printing Office), $425-445$.

1984. Cenozoic silicoflagellates from Rockall Plateau, Deep Sea Drilling Project Leg 81. In Roberts, D. G., Schnitker, D., et al., Init. Repts. DSDP, 81: Washington (U.S. Govt. Printing Office), 547-563.

1985. Tropical Pacific silicoflagellate zonation and paleotemperature trends of the Late Cenozoic. In Mayer, L., Theyer, F., et al., Init. Repts. DSDP, 85: Washington (U.S. Govt. Printing Office), 477-497.

1987. Eocene siliceous and calcareous phytoplankton, Deep Sea Drilling Project Leg 95. In Poag, C. W., Watts, A. B., et al., 
Init. Repts. DSDP, 95: Washington (U.S. Govt. Printing Office), 395-415.

Bukry, D., and Foster, J. H., 1973. Silicoflagellate and diatom stratigraphy, Leg 16, Deep Sea Drilling Project. In van Andel, T. H., Heath, G. R., et al., Init. Repts. DSDP, 16: Washington (U.S. Govt. Printing Office), 815-871.

1974. Silicoflagellate zonation of Upper Cretaceous to lower Miocene deep-sea sediment. J. Res. U.S. Geol. Surv., 2:303-310.

Bukry, D., and Monechi, S. 1985. Late Cenozoic silicoflagellates from the northwest pacific, deep sea drilling project leg 86: paleotemperature trends and texture classification. In Heath, G. R., Burckle, L. H., et al., Init. Repts. DSDP, 86: Washington (U.S. Govt. Printing Office), 367-397.

Ciesielski, P. F., 1975. Biostratigraphy and paleoecology of Neogene and Oligocene silicoflagellates from cores recovered during Antarctic Leg 28, Deep Sea Drilling Project. In Hayes, D. E., Frakes, L. A., et al., Init. Repts. DSDP, 28: Washington (U.S. Govt. Printing Office), 625-691.

1983. The Neogene and Quaternary diatom biostratigraphy of sub-Antarctic sediments, Deep Sea Drilling Project Leg 71. In Ludwig, W. J., Krasheninnikov, V. A., et al., Init. Repts. DSDP, 71, Pt. 2: Washington (U.S. Govt. Printing Office), 635-665.

1985. Middle Miocene to Quaternary diatom biostratigraphy of Deep Sea Drilling Project Site 594, Chatham Rise, southwest Pacific. In Kennett, J. P., von der Borch, C. C., et al., Init. Repts. DSDP, 90, Pt. 2: Washington (U. S. Govt. Printing Office, 863-885.

Deflandre, G., 1932. Sur la systématique des Silicoflagellés. Soc. Bot. France Bull., 79:494-506.

1950. Contribution a l'étude des silicoflagellidés actuels et fossiles. Microscopie, 2:72-108, 117-142, 191-210.

Dumitrica, P., 1967. Dictyocha bachmanni n. sp. et considérations phylogénétique Dictyocha crux-D. stauracantha-D. bachmanni. Cahiers Micropaléont., Sér. 1, No. 4:1-6.

1973. Paleocene, late Oligocene and post-Oligocene silicoflagellates in southwestern Pacific sediments cored on DSDP Leg 21. In Burns, R. E., Andrews, J. E., et al., Init. Repts. DSDP, 21: Washington (U.S. Govt. Printing Office), 837-883.

Ehrenberg, C. G., 1839. über die Bildung der Kreidefelsen und des Kreidemergels durch unsichtbare Organismen. K. Akad. Wiss. Berlin, Abh. 1838 (1840, separate 1839), 59-148.

1844. Untersuchungen über die kleinsten Lebensformen im Quellenlande des Euphrats und Araxes, so wie über eine an neuen Formen sehr reiche marine Tripelbildung von den Bermuda-Inseln vor. Ber. Verh. K. Preuss. Akad. Wiss. Berlin, 1844, 253-275. 1854. Mikrogeologie, das Erde und Felsenschaffende Wirken des unsichtbar kleinen selbständigen Lebens auf der Erde: Leipzig (Leopold Voss), 1-374.

Eldholm, O., Thiede, J., Taylor, E., et al., 1987. Proc. ODP, Init. Repts., 104: College Station (Ocean Drilling Program).

Frenguelli, J., 1940. Consideraciones sobre los silicoflagelados fósiles. Rev. Mus. LaPlata, Ser. 2, Vol. 2, Paleontology, 7: 37-112 (Jan. 31, 1940).

1935. Variaciones de Dictyochafibula en Gulfo de San Matias (Patagonia Septentrional): An. Mus. Argentino Cienc. Nat. Bernadino Rividavia, Protistol., 38:265-281.

Glezer, Z. I., 1960. Paleogenovye kremnevye zhgutikovye vodorosli (Silicoflagellatae) Zapadnoy Sibiri. Vses. Nauchno-Issledov. Geol. Inst. (VSEGEI), Inform. Sbornik, No. 35, Stratigr. i Paleont., 127-136.

1966. Silicoflagellatophyceae. In Gollerbakh, M. M., (Ed.), Cryptogamic plants of the U.S.S.R.: Akad. Nauk. SSSR, V. A. Komarova Bot. Inst. (Translated from Russian by Israel Program for Scientific Translations Ltd., Jerusalem, 1970, 7:1-363.)

Haeckel, E. H. P. A., 1862. Die Radiolarien (Rhizopodaradiaria). Eine Monographie: Berlin (Georg Reimer).

1887a. Report on the radiolaria collected by H.M.S. Challenger during the years 1873-1876. Rep. Sci. Results of H.M.S. Challenger 1873-6, 18:1-1803.

1887b. Cannorrhaphida. Challenger Report, 18: 1546-1569.

Hanna, G. D., 1931. Diatoms and silicoflagellates of the Kreyenhagen Shale: Mining in Calif., 197-201.
Ichikawa, W., Fuji, N., and Bachmann, A., 1964. Fossil diatoms, pollen grains and spores, silicoflagellates and arachaeomonads [sic] in the Miocene Hojuji Diatomaceous Mudstone, Noto Peninsula, central Japan. Sci. Rep. Kanazawa Univ., 9: 25-118.

Ichikawa, W., Shimizu, I., and Bachmann, A., 1967. Fossil silicoflagellates and their associated uncertain forms in Iida Diatomite, Noto Peninsula, Central Japan. Kanazawa Univ. Sci. Repts., 12: 143-172.

Jerkovic, L. 1965. Sur quelques silicoflagellides de Yugoslavie: Paris (Lab. Micropaleont., Inst. Paleont. Museum), 1-8.

Laws R. A. 1983. Preparing strewn slides for quantitative microscopical analysis: a test using calibrated microspheres. Micropaleontology, 29: $60-65$.

Lemmermann, E., 1901. Silicoflagellatae. Deutsche Bot. Gesell., Ber., 19: $247-271$.

Ling, H. Y., 1973. Silicoflagellates and ebridians from Leg 19. In Creager, J. S., Scholl, D. W., et al., Init. Repts. DSDP, 19: Washington (U.S. Govt. Printing Office), 751-775.

1975. Silicoflagellates and ebridians from Leg 31. In Karig, D. E., Ingle, J. C., et al., Init. Repts. DSDP, 31: Washington (U.S. Govt. Printing Office), 763-777.

Locker, S., 1974. Revision der Silicoflagellaten aus der Mikrogeologischen Sammlung von C. G. Ehrenberg. Eclog. geol. Helv., 67: 631646.

Locker, S., and Martini, E., 1985. Silicoflagellates and some sponge spicules from the southwest Pacific, Deep Sea Drilling Project, Leg 90. In Kennett, J. P., von der Borch, C. C., et al., Init. Repts. $D S D P$, 90: Washington (U.S. Govt. Printing Office), 887-924.

Mandra, Y. T., 1969. A new genus of silicoflagellata from an Eocene South Atlantic deep-sea core (Protozoa: Mastigophora). Occas. Pap. California Acad. Sci., 77.

Martini, E., 1972. Silicoflagellate zones in the late Oligocene and early Miocene of Europe. Senckenbergiana lethaea, 53: 119-122.

1979. Calcareous nannoplankton and silicoflagellate biostratigraphy at Reykjanes Ridge, Northeastern North Atlantic (DSDP Leg 49, Sites 407 and 409). In Luyendyk, B. P., Cann, J. R., et al., Init. Repts. DSDP, 49: Washington (U.S. Govt. Printing Office), 533-549.

Martini, E., and Müller, C., 1976. Eocene to Pleistocene silicoflagellates from the Norwegian-Greenland Sea (DSDP Leg 38). In Talwani, M., Udintsev, G., et al., Init. Repts. DSDP, 38: Washington (U.S. Govt. Printing Office), 857-895.

Moore, T. C., Jr., 1973. Method of randomly distributing grains for microscopic examination. J. Sediment. Petrol., 43: 904-906.

Perch-Nielsen, N., 1975. Late Cretaceous to Pleistocene silicoflagellates from the southern south west Pacific, DSDP Leg 29. In Kennett, J. P., Houtz, R. E., et al., Init. Repts. DSDP, 29: Washington (U.S. Govt. Printing Office), 677-721.

1985. Silicoflagellates. In Bolli, H. M., Saunders, J. B., and Perch-Nielsen, N. (Eds.), Plankton Stratigraphy: Cambridge, U.K. (Cambridge University Press), 811-846.

Schulz, P., 1928. Beiträge zur Kenntnis fossiler und rezenter Silicoflagellaten. Bot. Arch., 21: 225-292.

Shaw, C. A., and Ciesielski, P. F., 1983. Silicoflagellate biostratigraphy of middle Miocene to Holocene subantarctic sediments recovered by Deep Sea Drilling Project Leg 71. In Ludwig, W. J., Krasheninnikov, V. A., et al., Init. Repts. DSDP, 71: Washington (U.S. Govt. Printing Office), 687-737.

Stradner, H., 1961. Über fossile Silicoflagelliden und die Möglichkeit iher Verwendung in der Erdölstratigraphie. Erdoel Kohee, 14: 87-92.

Talwani, M., Udintsev, G., et al., 1976. Init. Repts. DSDP, 38: Washington (U.S. Govt. Printing Office).

Uchio, T., 1974. Tertiary nannoplankton stratigraphy of Sado Island, Niigata Prefecture and a proposal of the Braarudosphaera bigelowiiCoccolithupelagicus Zone for the Pliocene of Japanese oil fields of Japan Seaside. Japan Geol. Surv., 201: 235-254.

Date of initial receipt: 29 September 1987

Date of acceptance: 10 May 1988

Ms 104B-164 

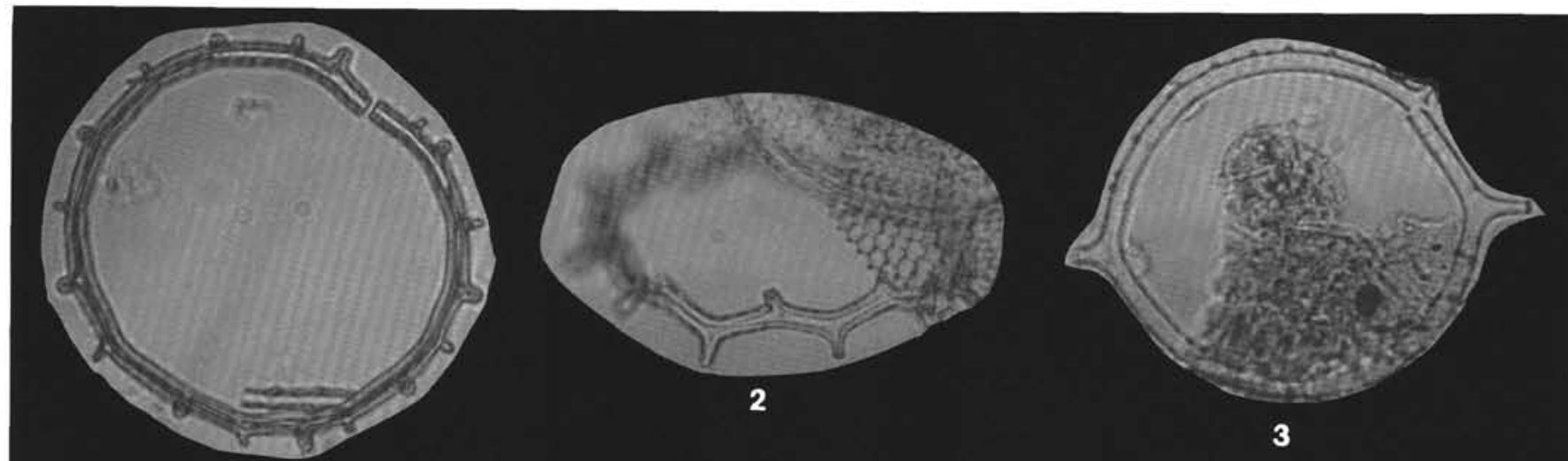

3
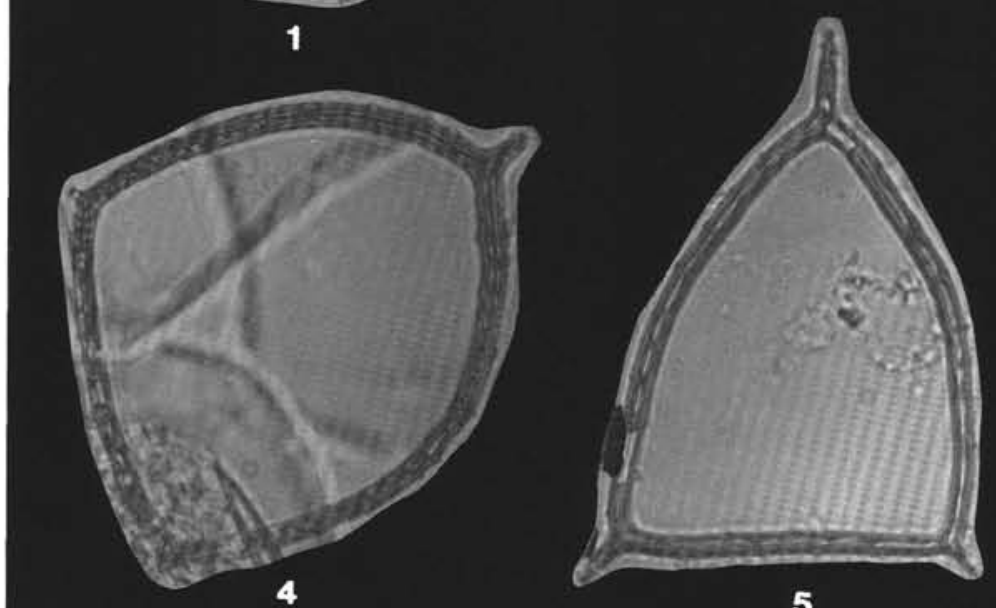

5

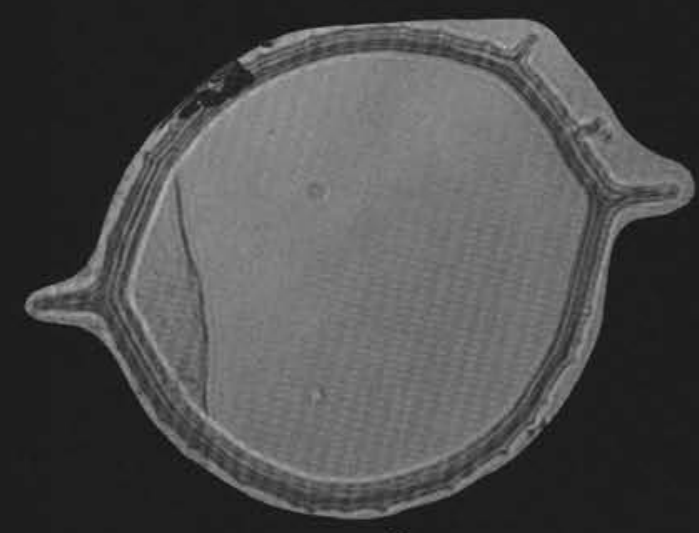

6

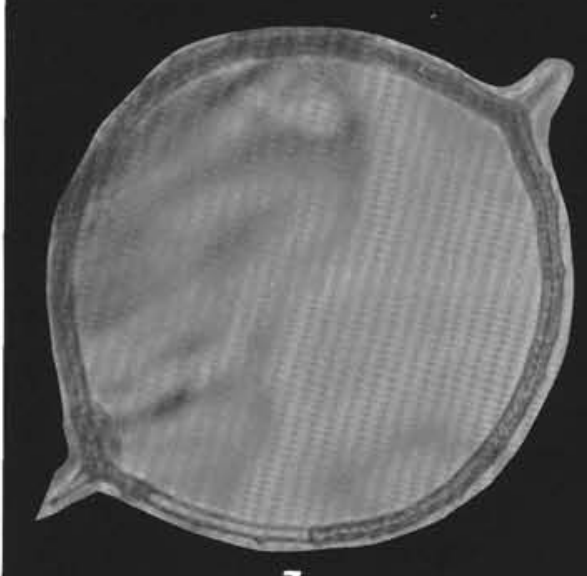

7

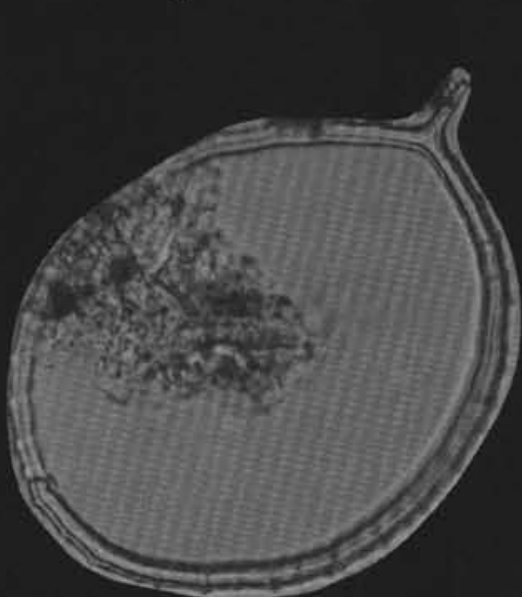

8

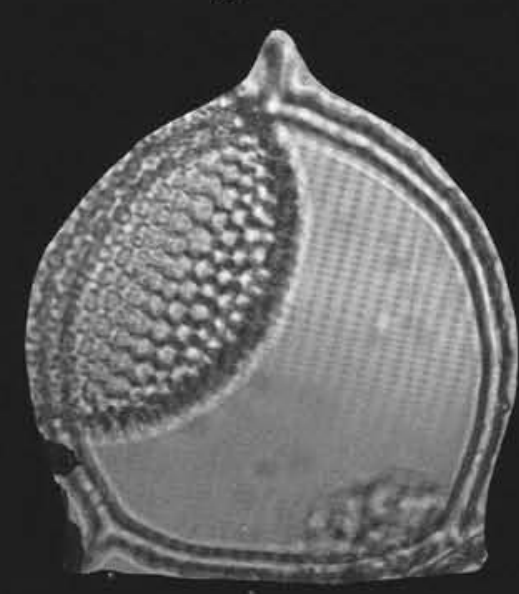

9

Plate 1. (All figures $\times 480$ ). 1-2. Bachmannocena circulus var. apiculata (Lemmermann) Bukry, 1. Section 104-642B-16H, CC, 2. Side view, Section 104-642C-18H, CC. 3-9. Bachmannocena diodon nodosa (Bukry) Bukry, 3. Three-spined form, Section 104-642B-16H, CC, 4. Rare three-spined triangular morphotype, Section 104-642B-16H, CC, 5. Rare three-spined triangular morphotype, Section 104-642B-13H, CC, 6. Three-spined form, Secton 104-642B-15H, CC, 7. Section 104-642B-13H, CC, 8. One-spined form, Section 104-642B-13H, CC, 9. Threespined triangular form with inflated sides. 


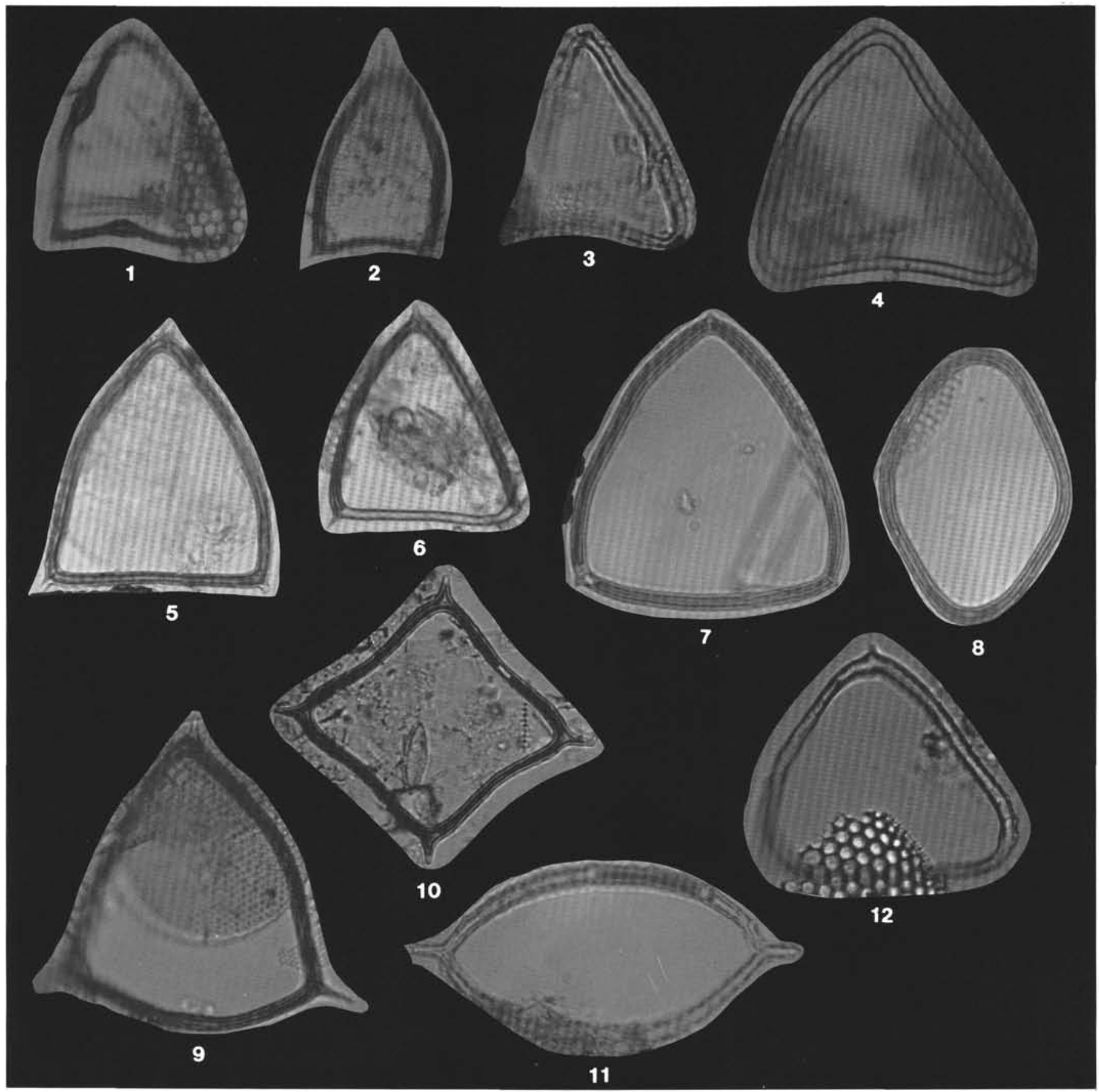

Plate 2. (All figures $\times 480$ ). 1-3. Bachmannocena apiculata curvata (Bukry) Bukry, 1. With bulbous thickenings, Section 104-643A-22X, CC, 2. Section 104-643A-22X, CC, 3. Section 104-643A-13H, CC. 4. Bachmannocena apiculata glabra (Schulz) Bukry, Section 104-643A-22X, CC. 5-6. Bachmannocena sp. cf. B. apiculata curvata (see taxonomic note), 5. Section 104-642D-4X, CC, 6. Section 104-643A-22X, CC. 7. Bachmannocena apiculata evexa (Bukry) Bukry, Section 104-642C-14H, CC. 8. Bachmannocena ovata (Bukry) Bukry, Section 104-642B-20H, CC. 9. Bachmannocena apiculata inflata Bukry, Section 104-643A-26, CC. 10. Bachmannocena schulzii (Martini and Müller) Bukry, reworked, 104-643A-12H, CC. 11. Bachmannocena diodon borderlandensis (Bukry) Bukry, Sample 104-642B-12H, CC. 12. Bachmannocena cf. apiculata inflata. (Bukry) Bukry, Section 104-643A-13H, CC. 


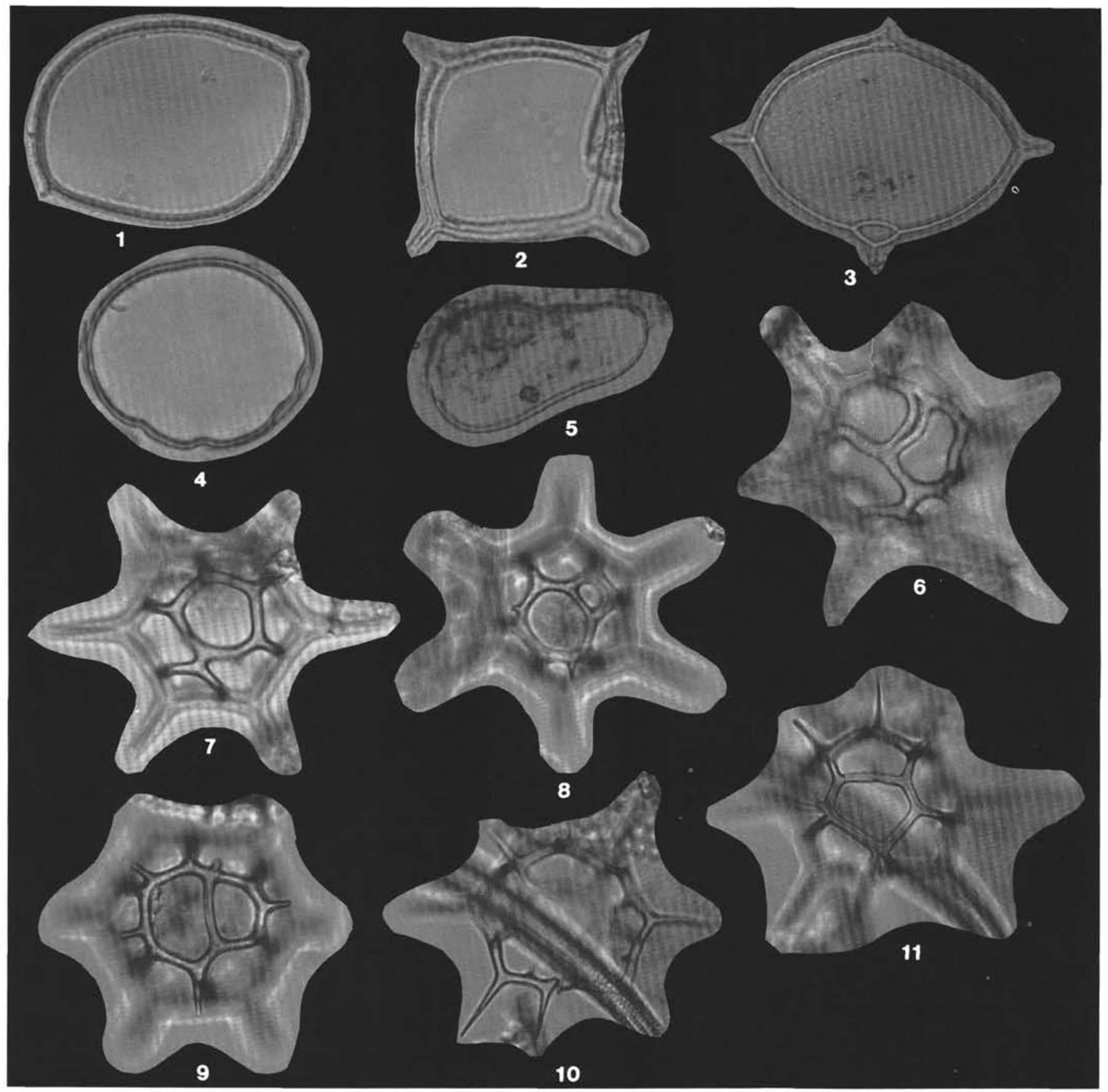

Plate 3. (All figures $\times 480$ ). 1. Bachmannocena diodon diodon (Ehrenberg) Locker, Section 104-642B-19H, CC. 2. Bachmannocena quadrangula (Ehrenberg ex Haeckel) Bukry, Section 104-642B-12H, CC. 3. Dictyocha brevispina (Lemmermann), nearly mesocenoid with only one small portal, Section 104-642B-1OH, CC. 4. Bachmannocena sp., with thin and wavy oval ring, Sample 104-643A-24H, CC. 5. Bachmannocena sp., with thin, pinched, pear-shaped ring, Section 104-644A-34H, CC. 7. Distephanus boliviensis (irregular), with five-sided apical apparatus and bifurcating lateral rod (not encountered in census), Section 104-643A-15H, CC. 6, 8-11. Distephanus boliviensis (cannopilean-irregular), see taxonomic notes (not encountered in census) 6., 8. Section 104-643A-15H, CC, 9. Section 104-643A-13H, CC. 10-11. Sample 104-643A-13H, CC 10. Basal focus. 11. apical focus. 


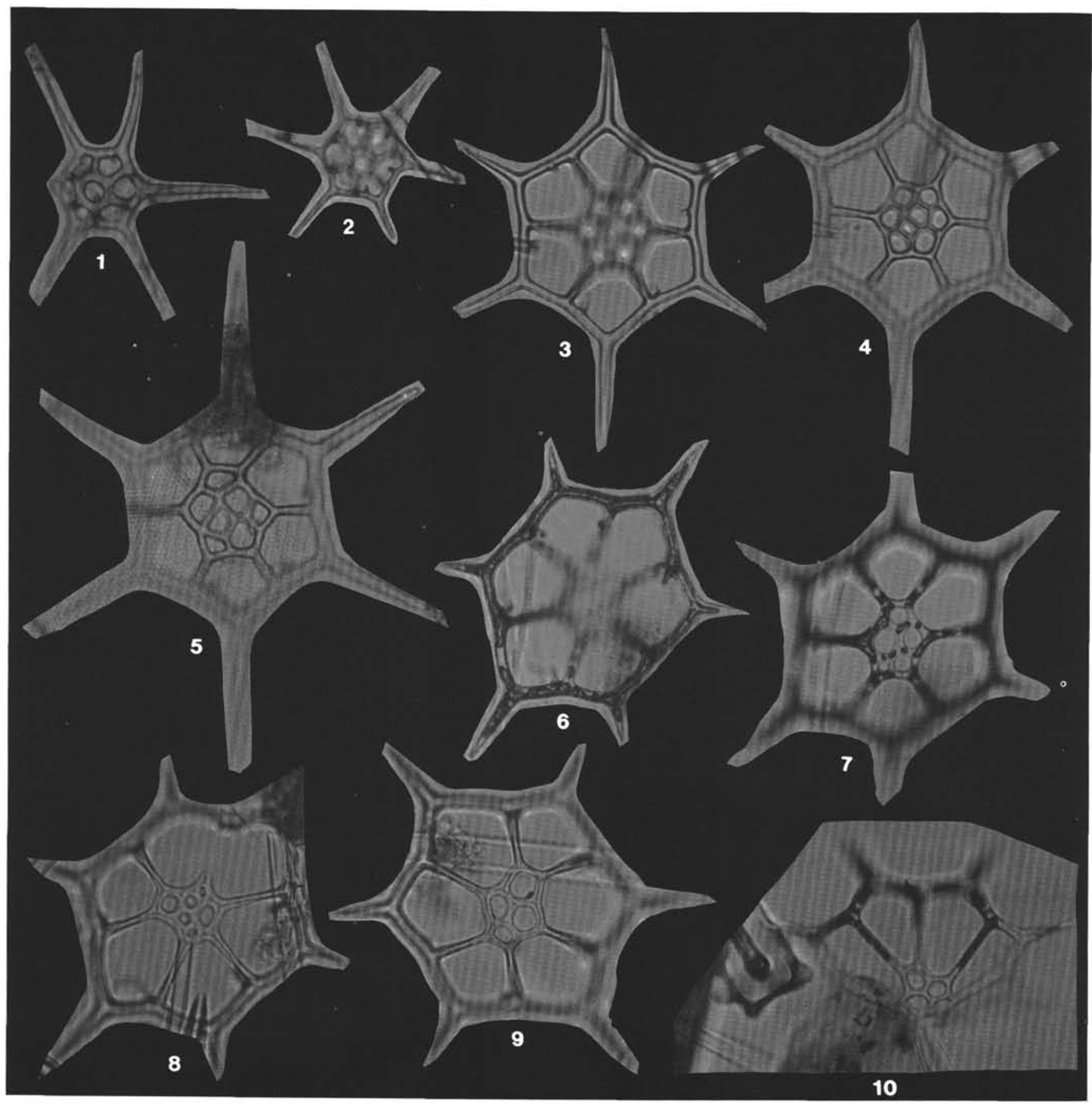

Plate 4. (All figures $\times$ 480). 1-2. Distephanus speculum s.l. (Ehrenberg) Haeckel, Section 104-644A-34H, CC. 3-4. Distephanus jimlingii (Bukry) Bukry, 3. Basal focus. 4. Apical focus, Section 104-642C-11H, CC. 5-7. Distephanus jimlingii/Ds. sulcatus (see taxonomic notes). 5. Sample 104-642C-11H, CC. 6. Basal focus and 7. Apical focus of same specimen from Sample 104-642C-10H, CC. 8-10. Distephanus sulcatus Bukry, Section 104-642C-1OH, CC. 


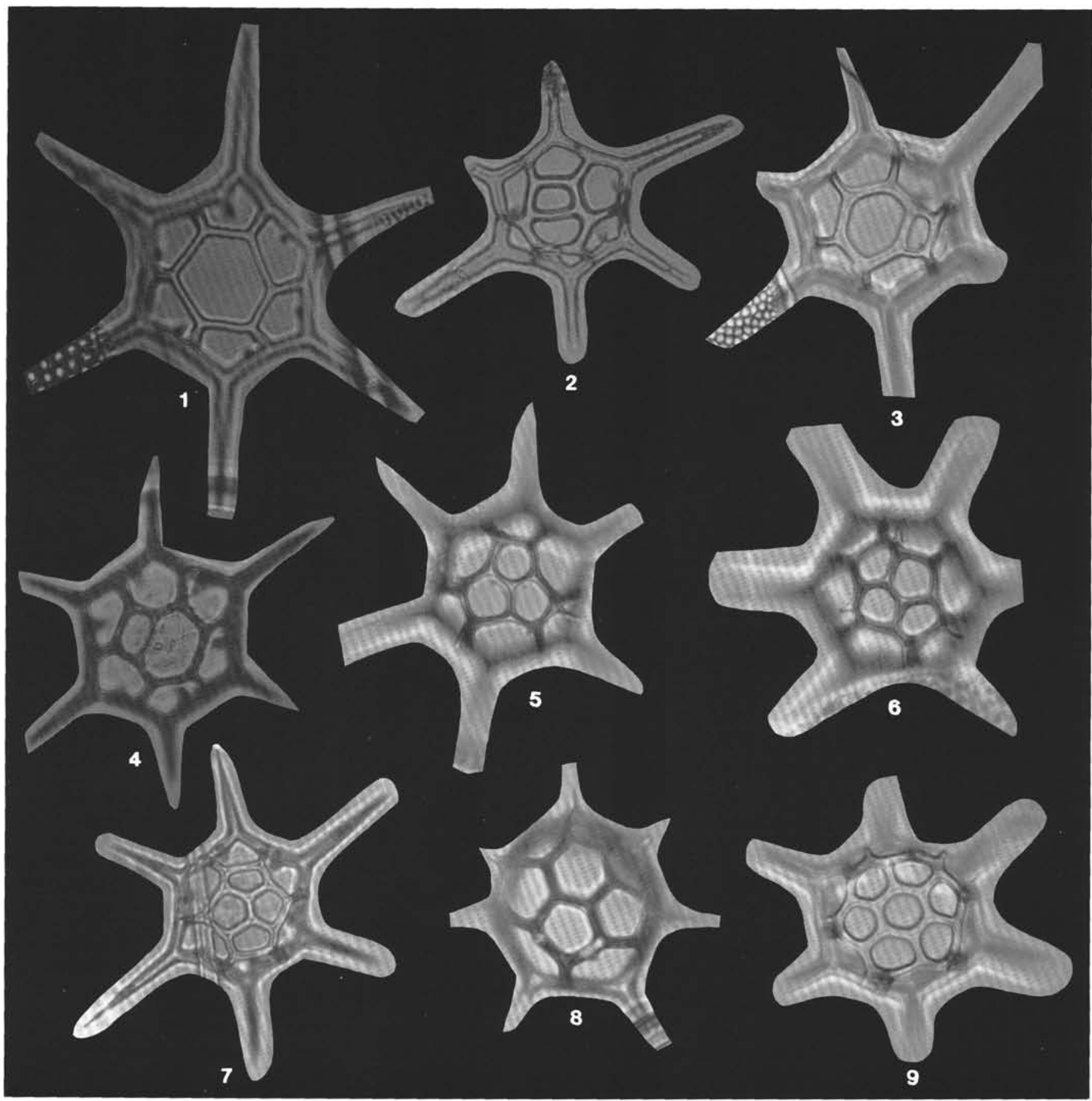

Plate 5. (All figures $\times 480$ ). 1. Distephanus boliviensis (Frenguelli) Bukry, Sample 104-642B-11H, CC. 2. Distephanus speculum (Ehrenberg) Haeckel, with two apical windows, Sample 104-642B-1OH, CC. 3-7. Distephanus boliviensis (cannopilean), 3. With two apical windows, Section 104-642D-2X, CC. 4. With two apical windows, Section 104-642B-1OH, CC. 5. With three apical windows, Sample 104-642D-2X, CC. 6. With four apical windows, Sample 104-642D-2X, CC. 7. with four apical windows, Section 104-642C-13H, CC. 8. Distephanus boliviensis (hemisphaericoid), equal spine lengths, apical apparatus filling interapical area. Section 104-642D-3X, CC. 9. Distephanus speculum hemisphaericus (Ehrenberg) Bukry, Section 104-642D-2X, CC. 


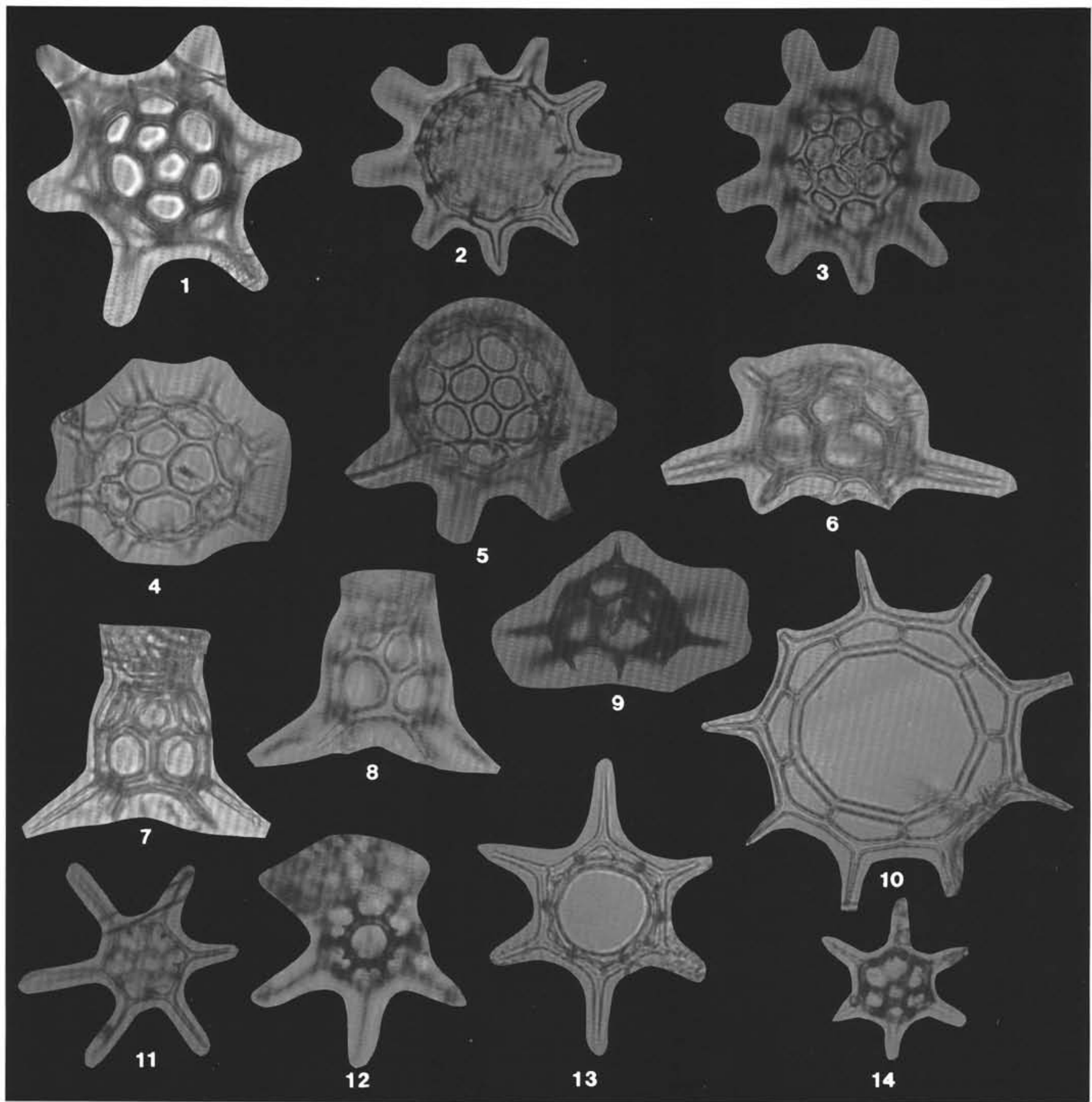

Plate 6. (All Figures $\times 480$ ). 1. Distephanus boliviensis (hemisphaericoid), Section 104-642D-3X, CC. 2-3. Caryocha cf. depressa (Ehrenberg) Bukry et Monechi, basal focus (2) and apical focus (3), Sample 104-643A-13H, CC. 4. Distephanus schulzii (Deflandre) Ciesielski, Section 104642B-24H, CC. 5. Caryocha aff. depressa, (Ehrenberg) Bukry et Monechi, nine-sided, five spines broken or not visible, Section 104-642D-2X, CC. 6. Caryocha depressa (Ehrenberg) Bukry et Monechi, side view, Section 104-642B-25H, CC. 7-8. Caryocha ernestinae (Bachmann) Bukry et Monechi, side view, Section 104-642C-18H, CC. 9. Caryocha sp. Section 104-643A-15H, CC. 10. Distephanus polyactis crassus Bukry, Section 104-642C-11H, CC. 11. Distephanus speculum, with one long, curved spine, Section 104-644A-34H, CC. 12. Distephanus speculum f. coronata Schulz, Sample 104-642C-9H-2, 103-105 cm. 13. Distephanus speculum minutus (Bachmann) Bukry, Section 104-642B-1lH, CC. 14. Distephanus speculum, Section 104-644A-34H, CC. 


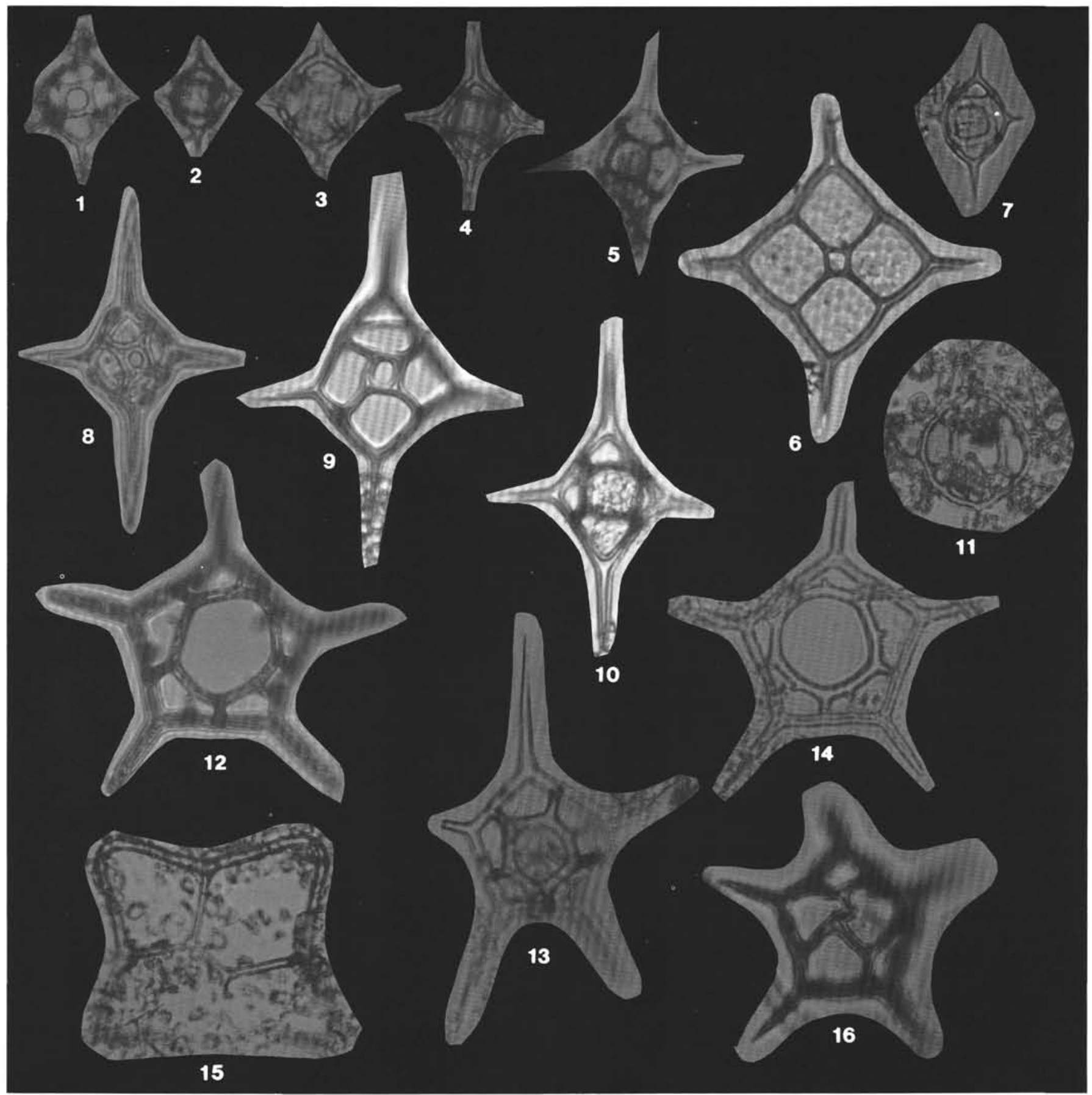

Plate 7. (All Figures $\times 480$ ). 1-3. Distephanus aff. slavnicii (Jerkovic) Bukry. 1. Sample 104-642C-21H-2 125-128 cm, 2. With elongate basal ring, Section 104-642C-21H-5, 125-128 cm, 3. Sample 104-642C-21-5, 125-128 cm. 4. Distephanus crux s. ampl., Sample 104-642C-21H-2, 125$128 \mathrm{~cm}$. 5. Distephanus crux scutulatus (Ehrenberg) Bukry, Section 104-643A-20X, CC. 6. Distephanus stradneri (Jerkovic) Bukry, Section 104643A-15H, CC. 7. Distephanus crux parvus (Bachmann) Bukry, Section 104-643A-13H, CC. 8. Distephanus longispinus (Schulz) Bukry, Section 104-642B-17H, CC. 9. Distephanus crux crux (Ehrenberg) Locker et Martini, Section 104-642D-2X, CC. 10. Distephanus crux scutulatus Bukry Sample 104-642D-4X, CC. 11. Distephanus crux ssp. 1, Sample 104-642C-19H-2, 125-128 cm. 12-14. Distephanus quinquangellus Bukry et Foster. 12. Section 104-642B-11H, CC. 13. With seven connecting rods (two extra) and very long spines, Section 104-643A-15H, CC. 14. With apical spines (= Distephanus speculum pentagonus armata Lemmermann), Section 104-642B-11H, CC. 15. Dictyocha quadria (Mandra) Martini et Müller, Sample 104-642C-9H-2, 103-105 cm. 16. Distephanus quinquangellus Bukry et Foster, with irregular apical apparatus, Section 104-643A-15H, CC. 


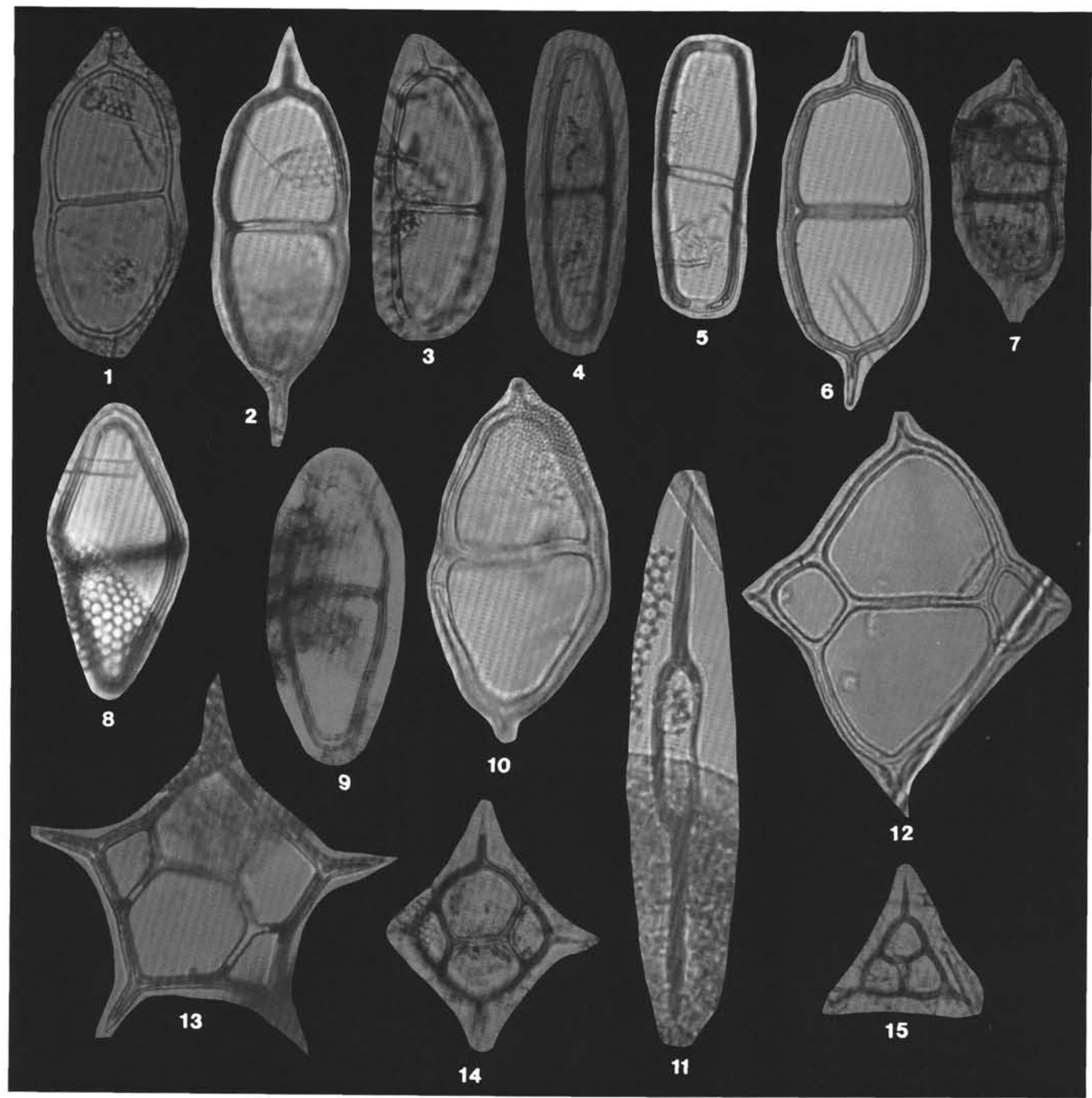

Plate 8. (All figures $\times 480$ ). 1-3, 6. Naviculopsis lata (Deflandre) Bukry, 1. Section 104-643A-28X, CC, 2. Section 104-642D-6X, CC, 3. Section 104-643A-28X, CC, 6. Section 104-642D-6X, CC. 4-5. Naviculopsis ponticula ponticula (Ehrenberg) Bukry, 4. Section 104-643A-30X, CC, 5. Section 104-642D-5X, CC. 7. Naviculopsis iberica Deflandre, Section 104-643A-30X, CC. 8. Naviculopsis sp., Section 104-642D-6X, CC. 9. Naviculopsis navicula (Ehrenberg) Deflandre, Section 104-643A-26X, CC. 10. Naviculopsis sp., Section 104-642D-6X, CC. 11. Naviculopsis constricta (Schulz) Bukry, Section 104-642C-14H, CC (reworked). 12. Dictyocha brevispina (Lemmermann) Bukry, Section 104-642C-12H, CC. 13. Dictyocha pentagona (Schulz) Bukry et Foster, Section 104-642C-19H, CC. 14. Dictyocha pulchella var. inflata Bukry, Section 104-643A28X, CC, basal accessory spines not visible. 15. Corbisema triacantha (Ehrenberg) Bukry et Foster, Section 104-643A-26X, CC. 